GEORGE J. HALL

Yale University

STEFAN KRIEGER

Yale University

\title{
The Tax Smoothing Implications of the Federal Debt Paydown
}

AFTER NEARLY THIRTY straight years of deficit spending, the fiscal position of the U.S. government has experienced a dramatic turnaround. In fiscal years 1998 and 1999, for the first time since the 1950s, the federal government ran back-to-back budget surpluses. With the government no longer a net borrower, the Treasury has started paying down the federal debt: debt held by the public fell from \$3.5 trillion in March 1998 to $\$ 3.0$ trillion in July 2000. And both the Office of Management and Budget $(\mathrm{OMB})$ and the Congressional Budget Office (CBO) are forecasting that these surpluses will continue over the next decade, ${ }^{1}$ in amounts large enough that the public debt will be fully redeemed in 2012. Although these official forecasts may prove too optimistic, it is reasonable to expect that the quantity of publicly held debt will shrink considerably over the next decade. ${ }^{2}$

The pending debt paydown has several implications for macroeconomic policy. This paper focuses on only one of these. All types of debt allow

We thank Tavneet Suri for excellent research assistance; V. V. Chari, Michael Fleming, Benjamin Friedman, Mark Gertler, Patrick Kehoe, William Nordhaus, Christopher Sims, and Warren Weber for comments; the Yale International Center for Finance for providing us the CRSP government bond files; Daniel Waggoner for providing us computer code with which to construct zero-coupon bond prices; and Mark Booth for providing historical data on the performance of Congressional Budget Office forecasts.

1. See Congressional Budget Office (2000) and Office of Management and Budget (2000).

2. See Auerbach and Gale (2000) for an alternative forecast and a discussion of the assumptions underlying the $\mathrm{CBO}$ forecast. 
the government to smooth taxes through time, but when debt is denominated in nominal dollars, it also allows the government to hedge against fiscal shocks. As the federal debt shrinks, the government's ability to shift the risk of adverse fiscal outcomes onto debt holders will be reduced considerably. To see this, consider the choices faced by a fiscal authority when an unexpected increase in spending occurs. To satisfy the government's net-present-value budget constraint, the fiscal authority can either raise taxes, now or in the future; cut spending in other areas, now or in the future; or impose a capital loss on existing bondholders, through inflation, higher interest rates, or explicit indexation to fiscal shocks. As the public debt falls, the government's ability to use this third option is diminished; hence either taxes or spending, or both, will become more variable. This paper illustrates this idea theoretically and document it empirically using data from the late 1800 s and from the post-World War II period.

The insight that debt can be used to hedge fiscal shocks is not new; indeed, it has been developed in a series of papers over the last quarter century. For example, Robert Barro concluded that tax rates should change only when unanticipated shocks change the discounted present value of the stream of primary surpluses. ${ }^{3}$ Thus, in an economy containing government debt and subject to stochastic shocks, the optimal path of tax rates follows a random walk regardless of the persistence properties of those shocks. Barro's partial-equilibrium model assumes a constant, non-statecontingent rate of return on debt and an objective function for the government that depends directly on tax rates rather than on consumption and output.

Robert Lucas and Nancy Stokey formulated a general-equilibrium model in which the government sets fiscal and monetary policy to maximize households' objective function. ${ }^{4}$ Debt plays two roles in their model. First, as in the Barro model, debt allows the government to smooth distorting tax rates over time. ${ }^{5}$ But in an important departure from the Barro model, optimal policy in Lucas and Stokey's framework involves the government issuing and retiring bonds with a state-contingent payoff: the amount paid these bondholders in a given period would depend on what unexpected changes to government expenditure had occurred this period.

3. Barro (1979).

4. Lucas and Stokey (1983).

5. Barro (1979). 
Through these state-contingent payoffs, the government effectively purchases "insurance" from the public against these fiscal shocks. Second, debt acts as a commitment device. The government cannot precommit itself to follow a given tax rate policy in the future; by modifying the current maturity structure of government debt, however, today's government can manipulate the incentives of future governments to alter tax rates. Under a rich enough and properly chosen debt structure, the government today can set the debt structure such that future governments will select the same future tax rate sequence that the present government would have chosen.

V. V. Chari, Lawrence Christiano, and Patrick Kehoe extend Lucas and Stokey's work by analyzing optimal fiscal and monetary policy within a neoclassical stochastic growth model. ${ }^{6}$ They put aside the important issues of commitment and time inconsistency. In contrast to Barro, they find that optimal tax rates on labor are essentially constant for plausibly parameterized models. ${ }^{7}$

In these models the government's optimal fiscal policy smooths tax rates in two ways. First, it imposes capital losses on existing creditors in response to surprise increases in current or future government spending, or it delivers capital gains to existing creditors in response to surprise decreases in current or future government spending. Second, it pays down the debt when government spending is low and is anticipated to rise, or conversely, allows the debt to rise when government spending is high and is anticipated to fall. Such a policy allows the government to smooth tax distortions over time while satisfying the government budget constraint.

Recently, Michael Woodford and Christopher Sims have independently shown that these optimal policy models can be viewed through the lens of the fiscal theory of the price level (FTPL). ${ }^{8}$ The FTPL reinterprets the present-value government budget constraint as an equilibrium condition in which the price level adjusts to keep the real value of government debt equal to the real present value of future government surpluses. Both Sims and Woodford argue that the optimal degree of price instability is implemented by a policy that consists of a constant level of distorting taxes and

6. Chari, Christiano, and Kehoe (1991, 1994). See also Chari and Kehoe (1999).

7. Barro (1979).

8. Woodford (1998); Sims (2000). Christiano and Fitzgerald (2000) and Sargent (2000) also present insightful discussions on the connection between the FTPL literature and the optimal fiscal policy literature. 
a zero expected short-term interest rate. ${ }^{9}$ Under such a regime, the price level fluctuates as it should to implement a Lucas-Stokey style policy. Through these changes in the price level, holders of nominal government debt receive real returns that depend on the current state of the world in the same way as in the Lucas-Stokey model. Indeed, simple policy rules directly implement what might appear to be complex state-contingent outcomes.

Following Lucas and Stokey, we present and solve a simple completemarkets model of optimal fiscal policy. In this model the government must finance a stochastic stream of purchases using distortionary statecontingent taxes on labor. The government may also issue debt with state-contingent returns. Since the U.S. government issues mostly nonstate-contingent debt, we interpret changes in taxes, inflation, and interest rates as ways in which the government can make the return on its debt state-contingent, as suggested by the FTPL approach. In our model the optimal tax rate on labor is essentially constant, and the return on debt absorbs most of the shocks to the government budget constraint.

In our model the government can costlessly implement these statecontingent returns on debt. However, we recognize that in the real world the changes in inflation necessary to implement optimal policy may impose substantial costs. Therefore we use our model to perform a variety of policy experiments designed to compute the value of these state contingencies. We find that, depending on the size of the government spending shocks, the value of state-contingent debt can range from a negligible 0.05 percent of consumption to a much more sizable 3.1 percent. These numbers suggest that using the outstanding public debt as a fiscal shock absorber is an attractive policy option, at least when the level of outstanding debt is large enough to keep the required variation in rates of return sufficiently small.

We analyze data from 1865 to 1893 and from the post-World War II period to document the state-contingent nature of debt. We study the second half of the nineteenth century because during that period the U.S. government faced a situation not unlike the one it faces today, namely, a steady stream of primary surpluses. In response, the government engaged in a debt buyback program similar to the one the Treasury launched in Janu-

9. This policy is non-Ricardian, since it may not satisfy the government budget constraint out of equilibrium for some values of the price level. 
ary 2000. We argue that fiscal and monetary policy during the post-Civil War period was consistent with the optimal policy implied by the model. For the post-World War II period we compute the state-contingent returns to holders of government bonds. We find that time paths of returns during this second period are in some ways inconsistent with the model's optimal policy.

Current fiscal policy may also be inconsistent with the model's optimal policy. The model provides a baseline for evaluating various contemporary policy choices and considering extensions to the analysis. Clearly, in future work, adding explicit costs for anticipated or unanticipated changes in the price level would make the model more realistic. It would also be desirable to include capital and investment in the model, but time inconsistency problems greatly complicate the analysis. Although our analysis is too simple and abstract for direct use by policymakers, it does provide insights into at least one implication of the pending debt paydown: without a large stock of nominal debt outstanding to absorb a given level of government spending shocks, either tax rates or returns on government debt, or both, will become more volatile.

\section{The Model}

This section formulates and solves a simple dynamic model to illustrate how state-contingent returns on debt act as a fiscal shock absorber. ${ }^{10}$ The model is designed to illustrate the main effects that arise when the government pursues optimal tax and debt management policies, without allowing for the complicated shock processes needed to match all aspects of the data. In the model, the government is faced with an uncertain path for its expenditure. It can impose state-contingent taxes on labor, and it can issue debt with state-contingent returns. The government chooses its tax and debt policies optimally in the sense that it maximizes the private sector's utility. We then run a set of policy experiments to quantify the costs associated with moving away from the optimal policy prescribed by the model.

That optimal policy keeps tax rates on labor close to constant and varies the return on debt to ensure that the government's present-value budget

10. This model is essentially the one described in section 2.3 of Chari and Kehoe (1999). 
constraint is adhered to. During periods of continuing high government expenditure, the government finds it optimal to give bondholders a low rate of return. To compensate, the government gives these bondholders relatively high rates of return when government purchases fall. In the model, changes in government purchases do not significantly alter the marginal deadweight loss for a given tax rate. The government wants to keep the marginal cost of distortionary taxation constant through time and across states of the world. Similar labor tax rates at all times and in all states of the world, associated with these kinds of state-contingent returns on government debt, help the government achieve this goal.

\section{The Framework}

Consider an economy in which, at each date $t$, the state of the world $s_{t}$ is characterized by the level of exogenously given government purchases $g\left(s_{t}\right)$. We assume that the level of government purchases evolves according to a Markov chain. Let $\mathbf{s}^{t}$ denote the history of states of the world up to and including time $t$; that is, let $\mathbf{s}^{t}=\left\{s_{0}, s_{1}, \ldots, s_{t}\right\}$. Let $\mu\left(\mathbf{s}^{t}\right)$ denote the unconditional probability of observing history $\mathbf{s}^{t}$.

There is a continuum of identical households. Each household receives utility from private consumption $c\left(\mathbf{s}^{t}\right)$ and disutility from providing labor services $l\left(\mathbf{s}^{t}\right)$. Households rank potential consumption and labor streams using the standard expected discounted utility function

$$
\sum_{t=0}^{\infty} \sum_{\mathbf{s}^{t}} \beta^{t} \mu\left(\mathbf{s}^{t}\right) U\left[c\left(\mathbf{s}^{t}\right), l\left(\mathbf{s}^{t}\right)\right] .
$$

There is no capital in this economy, and the production function is linear: $F\left[l\left(\mathbf{s}^{t}\right)\right]=z l\left(\mathbf{s}^{t}\right)$. Labor is paid its marginal product; the before-tax wage $w\left(\mathbf{s}^{t}\right)$ is always given by $z$.

The government sets a state-contingent linear tax rate on labor income, $\tau\left(\mathbf{s}^{t}\right)$, and trades one-period bonds, $b\left(\mathbf{s}^{t}\right)$. Let $\mathbf{R}\left(\mathbf{s}^{t}\right)$ denote the statecontingent return on government debt carried from period $t-1$ to period $t$. The government's budget constraint during period $t$ is

$$
g\left(\mathbf{s}^{t}\right)+\mathbf{R}\left(\mathbf{s}^{t}\right) b\left(\mathbf{s}^{t-1}\right)=b\left(\mathbf{s}^{t}\right)+\tau\left(\mathbf{s}^{t}\right) z l\left(\mathbf{s}^{t}\right),
$$

and the household budget constraint is

$$
c\left(\mathbf{s}^{t}\right)+b\left(\mathbf{s}^{t}\right)=\mathbf{R}\left(\mathbf{s}^{t}\right) b\left(\mathbf{s}^{t-1}\right)+\left[1-\tau\left(\mathbf{s}^{t}\right)\right] z l\left(\mathbf{s}^{t}\right),
$$


along with the restriction that $-\bar{b}<b\left(\mathbf{s}^{t}\right)<\bar{b}$ for some large value of $\bar{b}$. The initial level of debt, $b_{-1}$, and the initial return on debt, $\mathbf{R}_{0}$, are given. Summing equations (2) and (3) yields the economy-wide resource constraint:

$$
c\left(\mathbf{s}^{t}\right)+g\left(\mathbf{s}^{t}\right)=z l\left(\mathbf{s}^{t}\right) .
$$

This is essentially an Arrow-Debreu complete-markets economy with distortionary taxation. We have set the model up such that all borrowing and lending occurs between households and the government; no borrowing among households is explicitly allowed. However, since all households are identical, no private borrowing and lending will occur in equilibrium. Thus the equilibrium paths of $c\left(\mathbf{s}^{t}\right)$ and $l\left(\mathbf{s}^{t}\right)$ will be identical to those in an economy with complete contingent private claims markets. Furthermore, the introduction of multiperiod bonds would not affect any of the results, since such bonds can be synthesized from state-contingent single-period bonds.

To be precise, a competitive equilibrium in the model is a tax rate $\tau\left(\mathbf{s}^{t}\right)$; an allocation $c\left(\mathbf{s}^{t}\right), l\left(\mathbf{s}^{t}\right)$, and $b\left(\mathbf{s}^{t}\right)$; and prices $\mathbf{R}\left(\mathbf{s}^{t}\right)$ for all $\mathbf{s}^{t}$ such that

- given the taxes and prices, the allocation maximizes the households' objective function in equation (1), subject to its budget constraint in equation (3), and

- the government's budget constraint in equation (2) is satisfied.

Now consider the government's problem. We define a tax policy $\theta$ as $\tau\left(\mathbf{s}^{t}\right)$ for all $\mathbf{s}^{t}$. We assume that the government commits itself to a policy once and for all before the model is set in motion. Thus the government chooses $\theta$ at time zero, after which households choose their allocations. Since the household decision rules are functions of the government policy, the government takes into account how prices and allocations will respond to its policy.

A Ramsey equilibrium is a government policy $\theta$; a set of decision rules $c\left(\mathbf{s}^{t} \mid \theta\right), l\left(\mathbf{s}^{t} \mid \theta\right)$, and $b\left(\mathbf{s}^{t} \mid \theta\right)$; and prices $\mathbf{R}\left(\mathbf{s}^{t} \mid \theta\right)$ such that

— the policy $\theta$ maximizes

$$
\sum_{t=0}^{\infty} \sum_{\mathbf{s}^{t}} \beta^{t} \mu\left(\mathbf{s}^{t}\right) U\left[c\left(\mathbf{s}^{t} \mid \theta\right), l\left(\mathbf{s}^{t} \mid \theta\right)\right]
$$

subject to the government's budget constraint in equation (2), with allocations given by $c\left(\mathbf{s}^{t} \mid \theta\right), l\left(\mathbf{s}^{t} \mid \theta\right)$, and $b\left(\mathbf{s}^{t} \mid \theta\right)$ and prices given by $\mathbf{R}\left(\mathbf{s}^{t} \mid \theta\right)$, and 
-for every policy $\theta^{\prime}$, the decision rules $c\left(\mathbf{s}^{t} \mid \theta^{\prime}\right), l\left(\mathbf{s}^{t} \mid \theta^{\prime}\right)$, and $b\left(\mathbf{s}^{t} \mid \theta^{\prime}\right)$; the prices $\mathbf{R}\left(\mathbf{s}^{t} \mid \theta^{\prime}\right)$; and the policy $\theta^{\prime}$ are a competitive equilibrium.

We solve for the Ramsey equilibrium in two steps. First, we solve the households' problem. That is, we maximize the objective function in equation (1) subject to households' budget constraint in equation (3). From the first-order conditions of this problem and the government's budget constraint in equation (2) we derive the following implementability constraint:

$$
\sum_{t=0}^{\infty} \sum_{\mathbf{s}^{t}} \beta^{t} \mu\left(\mathbf{s}^{t}\right)\left\{\frac{U_{c}\left[c\left(\mathbf{s}^{t}\right), l\left(\mathbf{s}^{t}\right)\right] c\left(\mathbf{s}^{t}\right)+U_{l}\left[c\left(\mathbf{s}^{t}\right), l\left(\mathbf{s}^{t}\right)\right] l\left(\mathbf{s}^{t}\right)}{U_{c}\left[c\left(\mathbf{s}^{0}\right), l\left(\mathbf{s}^{0}\right)\right]}\right\}=\mathbf{R}_{0} b_{-1} .
$$

This constraint is the net-present-value government budget constraint, written in terms of the household's consumption and labor allocation and the marginal utilities that this allocation implies. The term inside the brackets is the primary surplus at time $t$. Second, we solve the government's Ramsey problem of maximizing the household's objective function in equation (5) subject to the implementability constraint in equation (6) and the resource constraint in equation (4). Since equation (6) is no longer written in terms of $g\left(\mathbf{s}^{t}\right)$ and $\tau\left(\mathbf{s}^{t}\right)$, the government can now be thought of as choosing household consumption and leisure directly.

For $t>0$, there is only one implementability constraint with a single Lagrange multiplier, but there are multiple resource constraints, one for each state of the world, with different Lagrange multipliers. This has important consequences for the Ramsey allocation. Given the resource constraint for any particular state of the world, a unique Ramsey allocation exists for that state of the world, independent of calendar time $t$ or the history $\mathbf{s}^{t-1}$ up to time $t$. In other words, the Ramsey allocation has the form $c\left(\mathbf{s}^{t}\right)=c\left[g\left(s_{t}\right)\right], l\left(\mathbf{s}^{t}\right)=l\left[g\left(s_{t}\right)\right], \tau\left(\mathbf{s}^{t}\right)=\tau\left[g\left(s_{t}\right)\right]$.

Consequently, the level of debt is both a forward-looking and a backward-looking object. It is forward-looking because at any point in time it is the discounted expected value of current and future primary surpluses. These surpluses are in turn only a function of government purchases, because output $z l\left[g\left(\mathbf{s}^{t}\right)\right]$ and the tax rate $\tau\left[g\left(\mathbf{s}^{t}\right)\right]$ are determined, in equilibrium, only by the level of government purchases $g\left(\mathbf{s}^{t}\right)$. The level of debt is backward-looking because these functions depend on the initial level of debt. Hence, once a particular Ramsey equilibrium has been 
selected by the initial level of debt, current government purchases and anything that helps predict future government purchases determine the level of current debt. Nothing else has any effect. Any state of the world with the same present and future expected levels of government purchases will be associated with the same level of outstanding debt, independent of calendar time and history. In particular, there is no tendency to pay down the debt or to let it rise over time. Paying down the debt does not equate the marginal costs of raising revenue across time and across states of the world and is therefore not an optimal policy. ${ }^{11}$

\section{Results under Two Shock Processes}

Before conducting the policy experiments, we assign a functional form to the household objective function and values to the parameters describing the preferences, technology, and government spending process. For the households' objective function we assume that

$$
U_{c}\left[c\left(\mathbf{s}^{t}\right), l\left(\mathbf{s}^{t}\right)\right] c\left(\mathbf{s}^{t}\right)=\ln \left[c\left(\mathbf{s}^{t}\right)\right]+v\left[1-l\left(\mathbf{s}^{t}\right)\right] .
$$

The length of a period in the model is one year. The annual discount factor $\beta$ is set equal to 0.96 , so that in the absence of shocks the annual real interest rate is about 4 percent. We set the leisure preference parameter $v$ to 2.75 , and we fix the level of technology in the production function, $z$, at 3. These parameter choices imply that households spend about one-third of their time endowment working.

Table 1 reports the means and standard deviations for six time series. The data are annual from 1941 to 1999 . We partition the sample into two periods: the World War II and early postwar period, 1941-49, and the later postwar period, 1950-99. Private consumption $c$ is measured by personal consumption expenditure for nondurable goods and services. Government purchases $g$ is measured by federal government consumption expenditure and gross investment. Output $y$ is simply the sum of $g$ and $c$. Since our measure of output is a subset of GDP, some of our computed ratios differ from those usually reported. We computed the real return on government debt, $r$, and the unexpected real return on government debt, $r-E(r)$, using the methodology described in the next section. The aver-

11. This result does not mean that it is suboptimal to pay down debt in anticipation of future increases in government purchases. It merely states that it is suboptimal to pay down debt in the expectation that future government purchases will be the same as today's. 


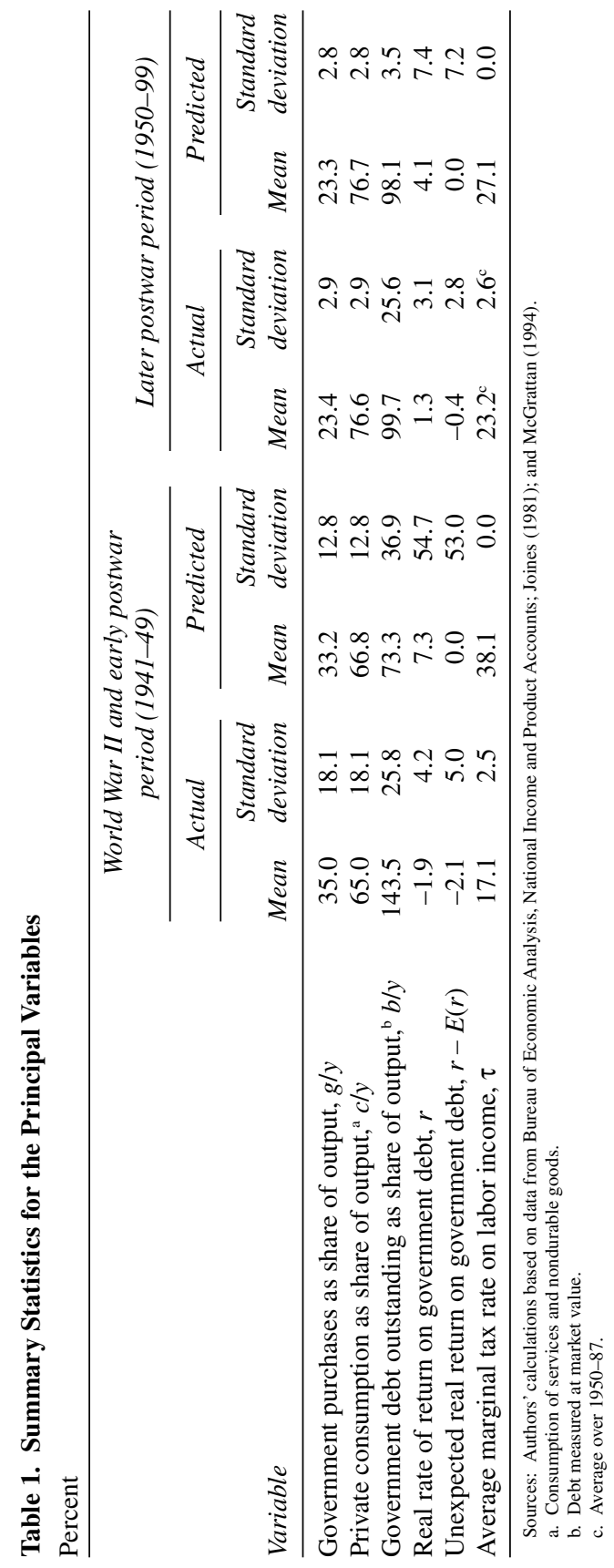


age marginal labor tax rate $\tau$ is taken from Douglas Joines and updated by Ellen McGrattan. ${ }^{12}$

We calibrate the government spending process twice, once for a large shock and once for a small shock. Having two calibrated cases allows us to address the importance of state-contingent debt both during relatively normal times and during crisis times, when especially large shocks can occur. The calibration for World War II and the early postwar period, the large shock case, is based on data from 1941 to 1949 , and that for the later postwar period, the small shock case, is based on data from 1950 to 1999 . We assume that government spending can take on one of only two discrete values. For the large-shock period we set $g_{\text {low }}=0.17$ and $g_{\text {high }}=0.57$, with a probability $\pi=0.75$ of remaining in the current state and a probability $1-\pi=0.25$ of switching to the other state. Although these shocks might seem large, note that the actual ratio of $g$ to $y$ varied from 0.25 in 1941, to 0.59 in 1944 , to 0.17 in 1947 . The transition probabilities imply that the average duration in each state is four years. We set the initial level of debt to 1.1. For the small-shock period we set $g_{\text {low }}=0.205$ and $g_{\text {high }}=0.28$. All the other parameters are the same across the two calibrations.

With these two parameterizations, the model roughly matches the mean and the standard deviation of the ratio of government purchases to output, $g / y$, and, for the second period, the mean of the debt-to-output ratio, b/y (table 1). Like most Arrow-Debreu models, this model cannot explain the risk-free rate puzzle: that is, it overestimates the real rate of return on government debt. ${ }^{13}$ But this simple model does highlight some of the basic lessons from the dynamic optimal taxation literature. Perhaps the most striking statistic in table 1 is that, under both calibrations, the standard deviation of the optimal path of labor tax rates is essentially zero. As already noted, Barro argued that labor tax rates should change only when unanticipated shocks change the discounted present value of the stream of primary surpluses, and indeed this occurs in the model, but only to a very trivial extent. ${ }^{14}$ Furthermore, fluctuations in $g$ are accommodated by changes in $y$, and so this tax smoothing implies that the time path of consumption is also virtually constant.

12. Joines (1981); McGrattan (1994).

13. Before the 1951 accord between the Treasury and the Federal Reserve, the Fed supported government securities at pegged prices.

14. Barro (1979). 
On the other hand, under the model's optimal fiscal policy, the return on government debt fluctuates considerably. For the large-shock calibration, when government purchases are high and remain high, the return on government debt is -21 percent. In contrast, when purchases drop from high to low, the return on debt is 135 percent. Conversely, when government purchases are low and remain low, the return on government debt is near 16 percent. When government purchases jump from low to high, this return plummets to -61 percent. Even for the small-shock calibration, the returns on government debt vary from -10 percent to +18 percent. Clearly the implied high volatility of the return to government debt is inconsistent with the data from both periods. We return to this issue below, but first we discuss the economic intuition behind these results.

These results demonstrate two features associated with the use of returns on government debt to absorb shocks to the net-present-value government budget constraint. First, expected returns on government debt are higher on average when government purchases are high than when they are low. This result follows from the higher expected growth rate of consumption when government purchases are high and are expected to fall, freeing up resources for consumption. Second, returns on government debt are extremely sensitive to surprise movements in government purchases. For instance, the difference between the return on government debt when government purchases switch from high to low, instead of persisting at a high level, is a huge 157 percent. These large differences in returns reflect the fact that a very large fraction of the absorption of the net present value of shocks to government purchases falls on debt holders (as opposed to taxpayers). The large differences in returns reflect what is necessary given the level of outstanding government debt.

The results also depend on the initial quantity of government debt. Ceteris paribus, higher initial levels of debt result in higher tax rates and lower consumption in all states of the world, as well as lower levels of expected utility. Furthermore, higher initial levels of government debt are associated with smoother expected returns and with less volatile return surprises. Figure 1 plots the standard deviation of the unexpected return on government debt for both calibrations, each as a function of the initial debt level. With more government debt outstanding, unanticipated returns can be less volatile while still buffering the shocks to the government's netpresent-value budget constraint. 
Figure 1. Volatility of Unexpected Returns on Government Debt ${ }^{\mathrm{a}}$

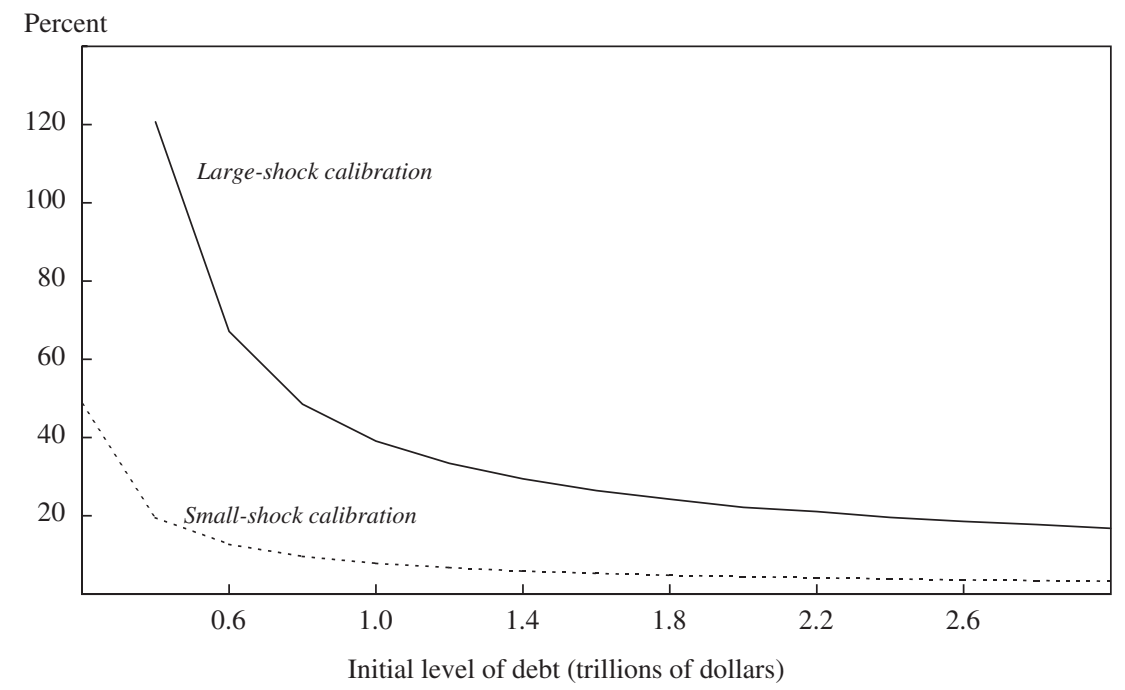

Source: Authors' calculations.

a. Standard deviation of the unexpected return on government debt as a function of the initial level of debt.

To sum up, the government's optimal tax and debt management policies aim to equalize the marginal costs of tax revenue across time and across states of the world. This aim has two major consequences. First, there is no long-run tendency to pay down outstanding debt; for a given level of initial debt, states of the world with the same current and expected levels of government purchases have the same level of outstanding debt. Second, the government makes heavy use of state-contingent returns on government debt to satisfy its net-present-value budget constraint. In particular, shocks to the expected net present value of government purchases are, for the most part, shifted onto government creditors through unanticipated changes in returns on government debt.

\section{Policy Experiments}

Clearly, the optimal policy implied by our simple, frictionless model overstates the use of state-contingent returns on government debt to smooth distortionary taxes. As we said at the outset, the United States does not issue explicitly state-contingent debt, but it can use unexpected 
changes in inflation and interest rates to implement state-contingent returns on its debt. In the real world there are costs associated with exercising these state contingencies (for example, from the need to change the price level when government debt is nominal, and from the need to change the term structure when government debt remains outstanding for more than one period). Since a benevolent government would take these costs into account when making policy, we want to compute the magnitude of the welfare gain associated with the ability to use state-contingent returns on debt to smooth taxes. Therefore, we run a set of experiments to estimate the following: the value of using government debt to smooth taxes, the value of issuing debt with state-contingent returns to smooth taxes, and the transition costs associated with both building up and paying down the debt.

For each of the policy experiments we compute the welfare loss imposed on households from deviating from the optimal policy. Table 2 reports the permanent change in consumption required to equate expected lifetime utility in each nonoptimal economy to that in the corresponding economy with an optimal policy.

Policy experiments 1 and 5 simply solve the model under the optimal policy described above for both the large- and the small-shock calibrations. In the first set of nonoptimal policies, we mandate that the government run a balanced budget. In policy experiments 2 and 6, labor taxes and the return on debt are still state contingent, but instead of maximizing the household's objective function, the government sets $\tau\left(\mathbf{s}^{t}\right)$ and $\mathbf{R}\left(\mathbf{s}^{t}\right)$ such that the primary surplus is zero each period. This balanced-budget policy is evaluated for both the small-shock and the large-shock calibrations. Under this balanced-budget rule, labor taxes are no longer constant, and household consumption becomes more variable. In both economies under the optimal policy, consumption is essentially constant; under a balancedbudget rule, the coefficient of variation of consumption is 0.04 for the small-shock economy and 0.05 for the large-shock economy. This variability in consumption is welfare reducing.

To be made indifferent between living in the small-shock economy under the optimal fiscal policy (policy experiment 1) and living in an identical economy with this balanced-budget rule in effect (policy experiment 2 ), households in the balanced-budget economy would require a 0.47 percent increase in consumption each period (table 1). For the large-shock calibration, the welfare loss associated with a balanced-budget rule rises 
Table 2. Results of Policy Experiments

\begin{tabular}{lccccc}
\hline & $\begin{array}{c}\text { Size of } \\
\text { government } \\
\text { spending } \\
\text { shock }\end{array}$ & $\begin{array}{c}\text { Is there } \\
\text { distortionary } \\
\text { taxation? }\end{array}$ & $\begin{array}{c}\text { Is there state- } \\
\text { contingent } \\
\text { debt? }\end{array}$ & $\begin{array}{c}\text { Is there a } \\
\text { balanced- } \\
\text { budget rule? }\end{array}$ & $\begin{array}{c}\text { Welfare loss } \\
\text { (percent of } \\
\text { permanent } \\
\text { consumption) }\end{array}$ \\
\hline 1 & Small & Yes & Yes & No & $\ldots$ a $^{\text {andment }}$ \\
2 & Small & Yes & Yes & Yes & 0.47 \\
3 & Small & Yes & No & Yes & 0.52 \\
4 & Small & No & Yes & No & -4.40 \\
5 & Large & Yes & Yes & No & $\ldots$ \\
6 & Large & Yes & Yes & Yes & 7.9 \\
7 & Large & Yes & No & Yes & 11.0 \\
8 & Large & No & Yes & No & -11.0 \\
1982 debt buildup & & & & & 0.3 \\
1999 debt paydown & & & & & \\
\hline
\end{tabular}

Source: Authors' calculations.

a. Baseline experiment.

considerably. To be made indifferent between living in the large-shock economy with an optimal fiscal policy (policy experiment 5) and one with the balanced-budget rule (policy experiment 6), households in the balanced-budget economy would require a 7.9 percent increase in consumption each period. This may seem like an implausibly large welfare loss, but recall that the large-shock calibration is based on the 1940s, when the United States was financing its war effort. Lee Ohanian, using a generalequilibrium model with production to compute the cost of financing the war under a balanced-budget policy, calculates the welfare loss relative to the actual policy to be about a 3 percent permanent increase in consumption. ${ }^{15}$ The main reason we obtain a higher welfare cost is that our model is calibrated to generate large wartime expenditures four out of every eight years rather than once over a four-year period.

Ideally, we would like to compute the value of issuing state-contingent debt rather than risk-free debt. However, this calculation is notoriously difficult, because the level of debt becomes a state variable. Albert Marcet, Thomas Sargent, and Juha Seppälä solve an optimal taxation model similar to the one presented above, assuming that the government can issue or own only one-period, risk-free debt. ${ }^{16}$ However, to ensure that the debt is

15. Ohanian (1997).

16. Marcet, Sargent, and Seppälä (2000). 
risk free, two additional restrictions must be placed on the government's problem. First, both households and the government must be restricted from issuing more debt than they can repay with certainty. Second, for each time $t>0$, the present value of the stream of primary surpluses must be known one period ahead. Thus, rather than a single implementability constraint, the government faces a sequence (one for each date $t$ ) of implementability constraints. Not surprisingly, computing equilibria with risk-free government debt is computationally burdensome.

To avoid these difficulties, for policy experiments 3 and 7 in table 2 we report welfare numbers for economies with non-state-contingent (riskfree) debt and a balanced-budget restriction. ${ }^{17}$ The incremental welfare loss of going from state-contingent to non-state-contingent debt under a balanced budget rule is relatively minor for the small-shock calibration ( 0.05 percent) but considerably larger for the large-shock calibration (3.1 percent). This calculation suggests that the government's ability to use its debt as a form of insurance is an important policy tool when the economy is faced with large shocks.

We also compute the welfare loss from the deficits of the 1980s. For this policy experiment we set $g_{\text {high }}=g_{\text {low }}=0.2425$, so that the model is now deterministic and the level of government spending is always the mean of the small-shock calibration. We set the initial quantity of debt such that the debt-to-output ratio equals its 1982 level. We then set the labor tax rate such that in sixteen years the debt-to-output ratio equals its 1998 level. After 1998 the government implements the optimal policy, given the 1998 debt level. We compare households' lifetime utility under this debt buildup policy to the lifetime utility received under the optimal policy. As table 2 reports, to make households indifferent in 1982 between the two policies, households in the debt buildup economy would need a permanent 0.3 percent increase in consumption.

More to the point of this paper, we also report in table 2 the transition costs from paying down the current federal debt. As in the previous experiment, we set $g=0.2425$, so that again the model is deterministic, and we set the initial quantity of debt such that the debt-to-output ratio equals its 1998 level. We then set the tax rate such that in twelve years the debt-tooutput ratio is 5 percent. We assume that after 2010 the government imple-

17. In solving the model in this case, we assumed that $c\left(\mathbf{s}^{t}\right) \approx c\left(\mathbf{s}^{t}, \mathbf{s}^{t-1}\right)$. 
ments the optimal policy given its new lower level of debt. We then compute the permanent change in consumption required to make households indifferent between the debt paydown policy and the optimal policy. In this case households would need a permanent 1.7 percent increase in consumption in each period to make them as well off as the households in the economy with optimal policy.

Why is it more expensive in utility terms to pay down the debt than to build it up? Under the debt buildup policy, during the first sixteen years both consumption and leisure are higher than under the optimal policy. When the day of reckoning occurs and the government decides to stop building up its debt, both consumption and leisure fall as taxes rise to service the higher level of debt. But this pain is postponed sixteen periods and thus discounted by $0.96^{16}=0.52$ in 1982 . In contrast, under the debt paydown policy the pain is all front loaded. During the first twelve years, consumption and leisure are lower than they would be under the optimal policy, as taxes are set higher than optimal to pay down the debt. After twelve periods, as the government switches to the optimal policy, both consumption and leisure are higher than they would be under the optimal policy, but in this case the gain is discounted by $0.96^{12}=0.61$ in 1998 .

These policy experiments also shed light on the costs of not paying down the debt in anticipation of increases in government transfers, such as Social Security outlays. Optimal policy requires that, in a world with perfect foresight, the tax rate today be set so that it need not be changed in the future, even if this means that outstanding government debt is run up or paid down temporarily. Deviations from this optimal policy that lead to the same changes in tax rates over time as in the two policy experiments outlined above have the same welfare costs. It turns out that the net present value of the funding shortfall in Social Security of 2 percent of GDP a year is roughly equal in magnitude to the 1980 s tax cuts. Hence, in the context of our model, that shortfall has the same associated welfare costs of 0.3 percent of permanent consumption.

For comparison, policy experiments 4 and 8 in table 2 report the welfare cost of the government not having access to lump-sum taxes. For the largeshock calibration, removing the tax distortions would improve welfare relative to optimal policy with distorting taxes (comparing experiment 8 with experiment 5) by 11 percent, measured in consumption units. Under the small-shock calibration, removing these tax distortions would improve welfare (comparing experiment 4 with experiment 1 ) by 4.4 percent, again 
measured in consumption units. Paying down the debt rapidly imposes about 40 percent of the costs imposed by not having access to lump-sum taxes under the small-shock calibration.

\section{Evidence on the Use of Debt for Hedging Fiscal Risk}

These theoretical policy experiments illustrate the important role that public debt plays in hedging against fiscal shocks. We devote this section of the paper to studying this phenomenon further by analyzing two periods in U.S. history: the late nineteenth century and the post-World War II period.

Figure 2 plots the U.S. federal debt as a percentage of GNP over the last 200 years. Since 1800 the ratio of debt to GNP has increased substantially on five occasions. Three of these increases were due to war: the Civil War, World War I, and World War II. The two peacetime increases occurred during the Great Depression and in the 1980s and early 1990s. These increases tended to be followed by relatively long periods of declining debt-to-GNP ratios.

\section{The Nineteenth Century}

The turn of the twenty-first century is not the first time the federal government has appeared to be on a path toward paying off the outstanding public debt. In 1834 the federal government had essentially paid off its debt, and for several years in the 1830s it turned federal surpluses over to the states. The federal government next achieved a steady stream of primary surpluses from 1866 to 1893 . The principal source of these surpluses was the Morrill Tariff Act of 1861, which kept tariff rates at wartime levels long after the Civil War ended in 1865 . In contrast to the 1830s, these surpluses were not handed over to states but instead were used to reduce the public debt accumulated during the war. An act of Congress in 1862 established a "sinking fund," through which the Treasury repurchased federal debt at market prices and distributed large capital gains to existing bondholders by repurchasing many of these bonds at a premium. ${ }^{18}$ This buyback program contributed to the fall in the nominal value of the

18. Following the terminology of the day, we state that the government paid a premium for a bond when it paid over par. 
Figure 2. Publicly Held Government Debt Outstanding, 1800-1999

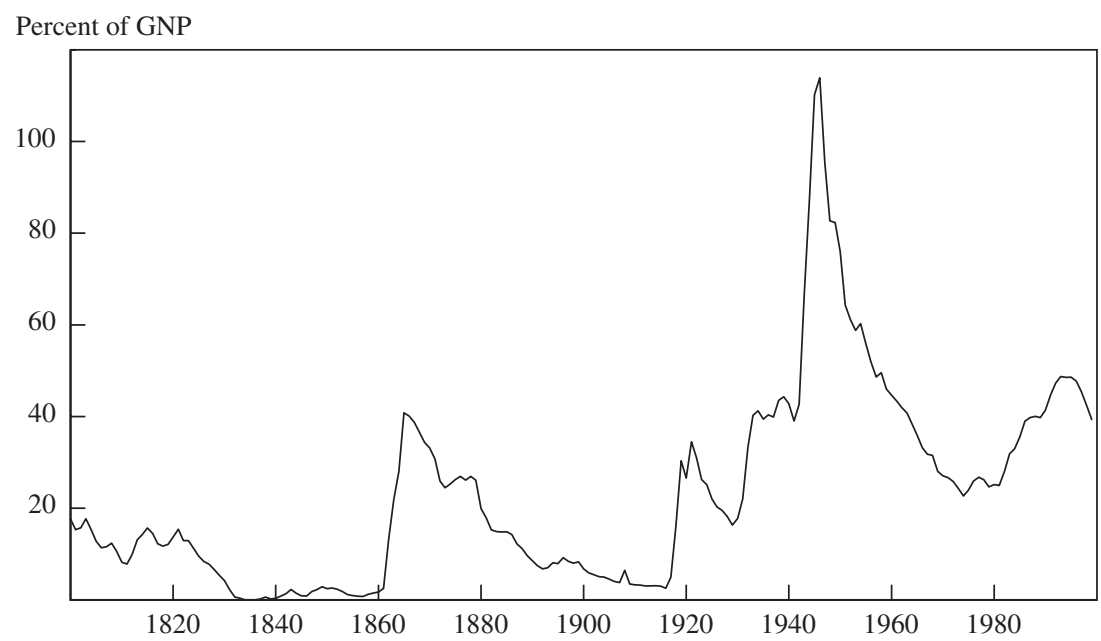

Source: Taus (1943), appendix V; U.S. Treasury, historical data; Mitchell (1993).

national debt from a high of $\$ 2.8$ billion in 1866 to just under $\$ 1$ billion in 1893.

The Treasury used two methods to buy back noncallable bonds. Under the first method it offered to buy back a particular bond series at par plus the next three coupon payments. Under the second, it invited bondholders to submit bids stating what price they would accept; the Treasury would then either accept or reject each bid. ${ }^{19}$ From 1869 to 1874 the Treasury repurchased, through the sinking fund, seven securities issued during the Civil War at premiums ranging from 8.4 to 15.8 percent. This, moreover, was during a period when consumer prices fell 15 percent (the Civil War inflation occurred during, not after, the war). Thus, after the war, as government spending fell from wartime to peacetime levels, government creditors received large real capital gains. This is the optimal policy implied by our simple model.

From 1875 through the 1880 s the Treasury continued to repurchase debt, generally at market prices. In 1880 and 1881 the Treasury paid modest premiums (under 4 percent) for some debt. By 1888 the entire short-

19. U.S. Department of the Treasury, Report of the Secretary of the Treasury, 1890. 
term debt had been retired, and no issues were due or callable. In response to the growing surpluses, the Treasury resumed purchasing bonds at premiums that sometimes went as high as 29 percent. Again, these purchases caused bond prices to increase, rewarding existing bondholders with large capital gains.

These repurchases of public debt at a premium were politically unpopular-a fact to which the annual reports of the Secretary of the Treasury during this period make repeated reference. For example, in the 1888 report, Treasury Secretary Charles Fairchild writes

Since the last annual report and after the completion of the sinking fund requirements for the year ended June 30,1888, no bonds were bought until there had been an expression of opinion by resolutions in both Houses of Congress that it was lawful and proper to invest the surplus in bonds at the premium necessary to obtain them. Under the then state of public opinion in many parts of the country upon this question, both as to its legality and propriety, it seemed wise to seek the cooperation of the Congress in this important matter. ${ }^{20}$

Nevertheless, the continuing surpluses forced the Treasury into a dilemma. It could continue to accumulate the surpluses, but this would continue to reduce the money supply, making it increasingly difficult for firms and private citizens to obtain loans, particularly in agricultural areas at harvest time. ${ }^{21}$ In 1887 the Treasury states

If we take into the Treasury large amounts of these circulating media in excess of what we pay out, there will soon not be money enough in the hands of the people for the purpose of business; serious derangement and disaster must follow. ${ }^{22}$

Alternatively, the Treasury could repurchase public debt on the open market and face the criticism of the public and Congress for "overpaying" to repurchase its own debt. ${ }^{23}$

Secretary Fairchild's preferred solution to this problem was to reduce the surplus by cutting taxes. In the 1888 report cited above he writes

... if this over taxation is not stopped, and if the Government is forced to continue to be the purchaser of its own bonds at the holders' prices, the loss to the people ... must be hundreds of millions of dollars.

20. U.S. Department of the Treasury, Report of the Secretary of the Treasury, 1888. 21. Taus (1943), p. 79.

22. U.S. Department of the Treasury, Report of the Secretary of the Treasury, 1887.

23. A third solution, holding the surplus at commercial banks, subject to the call of the government, was ruled out by legislation. See Taus (1943), p. 79. 
In the end, taxes were reduced. The McKinley Tariff Act of 1890 lowered tariffs on sugar and other important revenue-generating commodities. Government revenue also declined in the early 1890s as the economy slipped into a recession. By 1892 the Treasury had stopped repurchasing its debt at a premium, and by 1894 it had resumed issuing new debt.

From 1890 to the start of World War I the ratio of public debt to GNP was less than 10 percent. The work of Marcet, Sargent, and Seppälä suggests that because the federal government was unable to shift fiscal risk onto its creditors, tax rates and/or government spending should have been more volatile than they would have been otherwise. ${ }^{24}$ In future work it would be valuable to study tax policy during this period of low debt. Of course, tariffs continued to be the main source of federal revenue during this period; the Sixteenth Amendment to the Constitution, which authorized the federal income tax, was not ratified until 1913. More generally, it would be interesting in future work to look at the relative variability of tax rates across periods with high and low levels of public debt.

To sum up, the second half of the nineteenth century has much to tell us about optimal fiscal and monetary policy in a time of surpluses. For almost three decades the government ran an uninterrupted stream of primary surpluses. Over this period, tax rates were essentially left unchanged. The Treasury launched an explicit debt buyback program, which helped engineer a significant reduction in the outstanding public debt. It was also a time of steady deflation and a time during which holders of government bonds received high rates of return in response to positive fiscal shocks. These facts correspond with the predictions of neoclassical theory about optimal fiscal and monetary policy. As the next section shows, however, the realized returns to government debt in the post-World War II period are in several key ways inconsistent with this optimal policy.

\section{The Post-World War II Period}

It is well understood that the interest costs on government debt are often overstated, particularly during periods of high inflation. These overstatements occur because the government fails to account properly for the real 
capital losses that its creditors experience during inflationary periods. ${ }^{25}$ Building on previous work by Sargent and Sims, we compute the government's real interest costs and seigniorage revenue in the period after World War II. ${ }^{26}$ We then decompose the government's period-by-period budget constraint to isolate anticipated and unanticipated interest expenses and seigniorage revenue for this period.

To connect the theory presented above with available data on U.S. Treasury securities, we compute the debt that the government owes at each date in the future. Let $s_{j, t}$ denote the number of time $t+j$ dollars that the government has promised to deliver as of time $t$. To compute $s_{j, t}$ from historical data we sum all of the principal and coupon payments the government has promised to deliver at time $t+j$ as of time $t$. Thus we make no distinction between a coupon payment and a principal payment.

One can regard a coupon bond as a bundle of pure discount bonds of differing maturities. We can then price a coupon bond by unbundling it into a set of pure discount bonds, valuing each component individually, and adding up the values of the components. In other words, we strip the coupons from the bond and price the bond as a weighted sum of pure discount bonds of maturities from $1,2, \ldots, j$. The market and the government do this in actuality: prestripped coupon bonds are available in the market.

Let $a_{j, t}$ be the number of time $t$ goods that it takes to buy a dollar delivered at time $t+j$. Put another way, $a_{j, t}$ is the price (in goods) at time $t$ of a zero-coupon (pure discount) bond maturing $j$ periods ahead. Since zerocoupon bond prices were not directly observable until prestripped coupon bonds were introduced in 1985, we extract the nominal implicit forward rates from the bill and coupon bond price data. We then convert these nominal forward rates on government debt into prices of claims on future dollars in real terms. The government's budget constraint at time $t$ is then

$$
a_{0, t} m_{t}+\sum_{j=1}^{n} a_{j, t} s_{j, t}=a_{0, t} m_{t-1}+\sum_{j=1}^{n} a_{j-1, t} s_{j, t-1}+d e f_{t},
$$

where $a_{0, t}$ is the inverse of the price level and $d e f_{t}$ is the real value of the primary deficit. The left-hand side of equation (8) is the sum of the value of the monetary base at the end of period $t, a_{0, t} m_{t}$, and the value of interest-

25. See, for example, Olivier Blanchard and Jeffrey Sachs, "There Is No Significant Budget Deficit," New York Times, March 6, 1981, p. A26. See also Sargent (1993), and Hall and Sargent (1997).

26. Sargent (1993); Sims (2000). See also Hall and Sargent (1997). 
bearing debt at the end of period $t$. The real value of interest-bearing debt is computed by taking the product of the number of dollars of time $t+j$ that the government has sold in the form of period $j$ pure discount bonds, $s_{j, t}$, and the corresponding prices in terms of goods of time $t, a_{j, t}$, and then summing this product (or value) over all such outstanding bonds, $j=1$, $\ldots, n$. The right-hand side of equation (8) is the sum of the value of the monetary base at the beginning of the period, the real value of the outstanding debt that the government owes at the beginning of the period, and the real value of the primary deficit. By writing the government budget constraint this way, we implicitly treat money holders and bondholders symmetrically. We view the monetary base as simply a matured government bond. Furthermore, we are folding the Federal Reserve into the government.

Equation (8) can be rearranged to take the following form:

$$
\begin{aligned}
a_{0, t} m_{t}+\sum_{j=1}^{n} a_{j, t} s_{j, t} & =\left(a_{0, t}-a_{0, t-1}\right) m_{t-1}+\sum_{j=1}^{n}\left(a_{j-1, t}-a_{j, t-1}\right) s_{j, t-1} \\
& +a_{0, t-1} m_{t-1}+\sum_{j=1}^{n} a_{j, t-1} s_{j, t-1}+d e f_{t} .
\end{aligned}
$$

These two forms of the budget constraint are algebraically equivalent. The left-hand side of the budget constraint in equation (9) is still the real value of government debt outstanding at the end of period $t$. However, equation (9) breaks the first two terms on the right-hand side of equation (8) into a cost-of-funds component and a previous-value component. The first term on the right-hand side of the budget constraint in equation (9) represents the borrowing "costs" on the monetary base; this "cost" is the negative of seigniorage. The second term represents borrowing costs on interest-paying government debt, and the third and fourth terms are the values at time $t-1$ of the monetary base and interest-bearing debt, respectively. The cost-of-funds term on the interest-bearing debt can be decomposed as

$$
\begin{aligned}
E_{t-1} \sum_{j=1}^{n}( & \left.a_{j-1, t}-a_{j, t-1}\right) s_{j, t-1} \\
& +\left[\sum_{j=1}^{n}\left(a_{j-1, t}-a_{j, t-1}\right) s_{j, t-1}-E_{t-1} \sum_{j=1}^{n}\left(a_{j-1, t}-a_{j, t-1}\right) s_{j, t-1}\right] .
\end{aligned}
$$

The first term in equation (10) is the one-period-ahead anticipated cost of funds, and the second the unanticipated cost of funds. Since $a_{j, t-1}$ and $s_{j, t-1}$ 
are both known at time $t-1$, we need only compute the one-step-ahead expectation of $a_{j-1, t}$ for $j=1, \ldots, n$.

Likewise, the seigniorage term in equation (9) can be decomposed as

$$
E_{t-1}\left(a_{0, t}-a_{0, t-1}\right) m_{t-1}+\left[\left(a_{0, t}-a_{0, t-1}\right) m_{t-1}-E_{t-1}\left(a_{0, t}-a_{0, t-1}\right) m_{t-1}\right],
$$

where the first term is the negative of expected seigniorage, and the second the negative of unexpected seigniorage.

Figures 3 and 4 report and decompose the federal government's historical cost of funds using annual end-of-year data from 1941 to 1999. The bond price and quantity data are from the CRSP Monthly U.S. Government Bond File. ${ }^{27}$ We fit a zero-coupon forward curve from the coupon bond price data by means of Daniel Waggoner's cubic spline method. ${ }^{28}$ Waggoner fits the zero-coupon one-period forward-rate curve with a cubic spline employing a set of roughness criteria to reduce oscillations in the approximated curve. The value of the currency $a_{0, t}$ is the inverse of the December observation of the consumer price index. The expected value of the currency is computed monthly from a Bayesian vector autoregression (BVAR) using the consumer price index, industrial production, and the AAA bond rate.

Figure 3 contrasts our computed cost-of-funds series with the Treasury's official interest cost series. Our computed costs of funds are lower, on average, and considerably more volatile. ${ }^{29}$ Perhaps the most striking event in our series is the large capital loss imposed on bondholders right after World War II. As figure 3 shows, bondholders received a large negative return on government securities in 1946. The government's real borrowing costs were negative during other periods as well: in 1950 with the outbreak of the Korean War, during the high-inflation episodes of the 1970s, and in 1994 with the steep fall in bond prices. Overall, the real annual return on government debt has averaged only 0.8 percent since 1941. If we drop the first six years of our sample, the Treasury's real

27. In the CRSP data set the quantity of publicly held marketable debt goes back only to 1960 . We extended this series using data from the Treasury Bulletin.

28. Waggoner (1997).

29. The Treasury's calculations include some assets (such as savings bonds and some securities issued to state and local governments) that are not included in our analysis, and so these two series are not strictly comparable. Nevertheless, we believe that adding these assets to our analysis would not meaningfully change the results. 
Figure 3. Official and Calculated Interest Costs of Federal Debt, 1941-99

Percent of expenditure

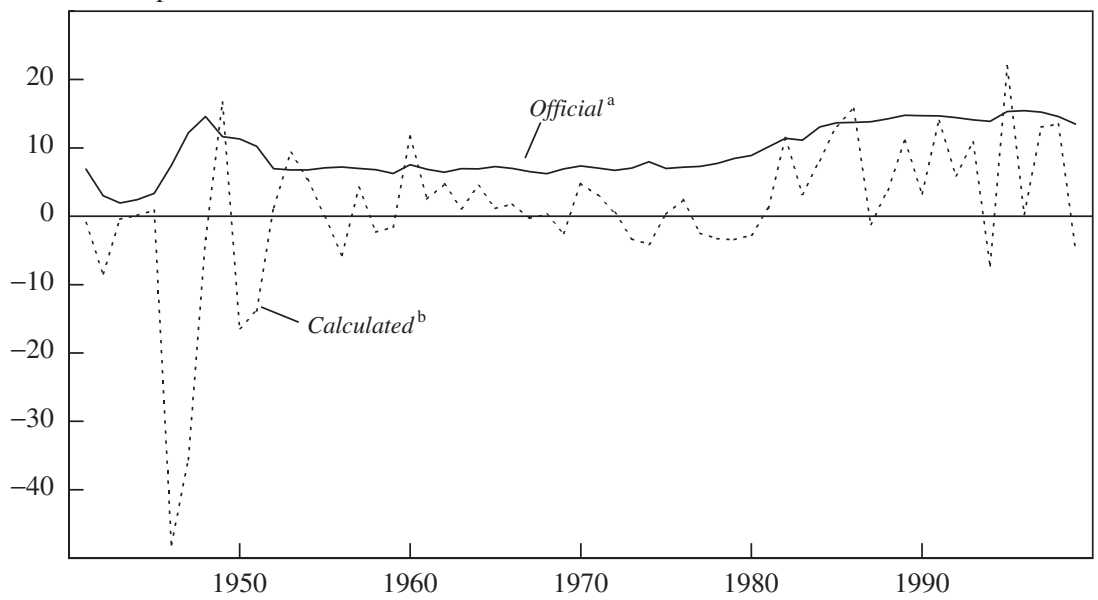

Source: Authors' calculations based on data from CRSP U.S. Government Bond File (University of Chicago) and U.S. Treasury. a. Ratio of interest payments as reported by the Treasury to total expenditures.

b. Ratio of cost of funds on interest-bearing debt as calculated by equation (10) to total expenditures.

\section{Figure 4. Expected and Unexpected Components of the Cost of Federal Debt,} 1947-99

Percent of expenditure

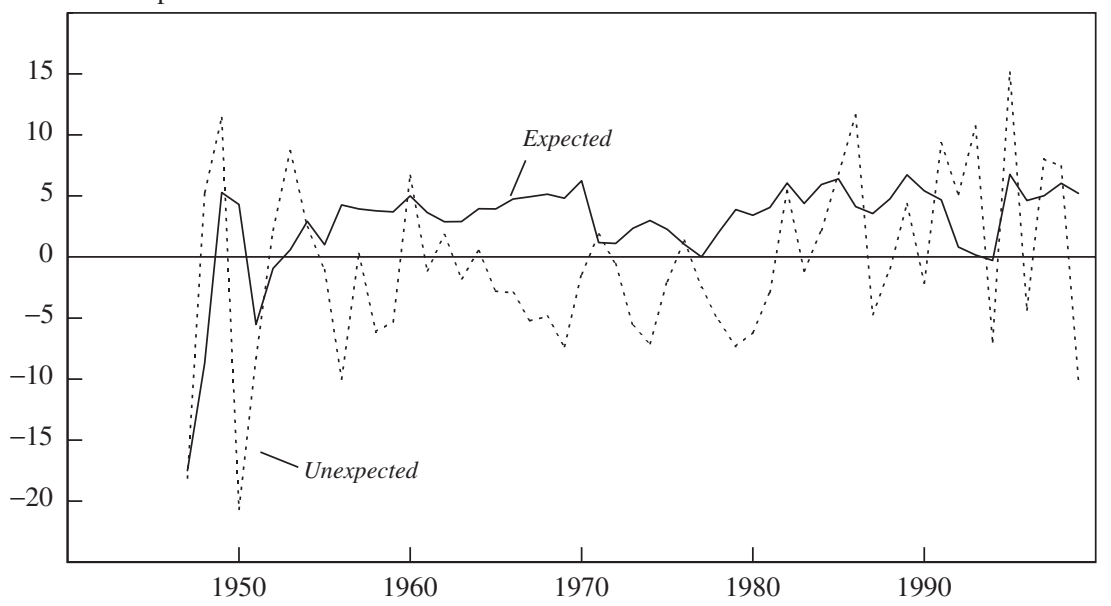

Source: Authors' calculations based on data from CRSP U.S. Government Bond File and U.S. Treasury. 
annual interest costs still average only 1.2 percent. Thus, when measured correctly, the Treasury's borrowing costs have historically been very low.

Figure 4 breaks down real returns on Treasury debt from 1947 to 1999 into their expected and unexpected components. ${ }^{30}$ These results are consistent with similar calculations done by Sims. ${ }^{31}$ In particular, much of the capital loss incurred in 1950, with the outbreak of the Korean War, appears to have been unanticipated. Similarly, during the late 1960s, government creditors effectively helped pay for the Great Society and the Vietnam War, as the government unexpectedly inflated away some of the real value of the outstanding debt. For the most part, these unanticipated returns remained negative in the 1970s, as the government offset the fiscal stress of the two oil crises. ${ }^{32}$ During the 1980s and 1990s, as inflation subsided, bondholders generally received positive unanticipated returns. The most striking exception to this is 1994, when the Fed began raising shortterm interest rates, thus setting off a sharp decline in the bond market.

At first glance, these returns are broadly consistent with the predictions of the model. Both anticipated and unanticipated capital losses to bondholders are associated with times of large increases in government expenditure or large reductions in government revenue. Likewise, anticipated and unanticipated capital gains to bondholders are associated with times when shocks to the primary surplus were positive. However, the model's implications for the optimal timing of gains and losses are the exact opposite of what we see in the post-World War II data. The most stark exam-

30. Our one-year-ahead forecasts of inflation are unreliable during the mid-1940s. In particular, our BVAR had considerable trouble reconciling the fall in industrial production with the steep rise in prices that occurred at the end of World War II. Since the expected inflation series produced by the BVAR seems sensible for the remainder of the sample, we truncated the decomposed series in 1947.

31. Sims (2000).

32. We are likely overstating the magnitude of unanticipated capital losses during the 1960s and 1970s. It is clear from figures 5 and 6 that our series for the unanticipated and anticipated cost of funds consistently move in opposite directions during the 1960s and 1970s. During these two decades the BVAR systematically underestimates inflation. Thus we are perhaps overestimating the anticipated returns for this period and underestimating the unexpected returns. We have made some attempts to improve the performance of our inflation forecasts, but we have been unable to find a specification that does a good job of forecasting the consumer price index throughout our sample. 
ple of this is the huge negative return imposed on government creditors immediately following World War II. This capital loss is in sharp contrast both to the post-Civil War experience, discussed in the previous subsection, and to the implications for optimal policy from our model. The model implies that bondholders should have suffered a capital loss at the beginning of the war and a large positive return immediately after the war.

This observation is not new with us. For example, at the 1993 Macroeconomic Annual Meeting, during the discussion of a paper by McGrattan and R. Anton Braun, Robert Hall noted that

traditionally the government induced bondholding and an increased labor supply by promising, contingent on winning the war, postwar deflation. For example, this was the approach taken in the United States during the Civil War and, to some extent, after World War I. World War II was the first clear situation in which the government failed, opportunistically in fact, to deliver on the implicit promise of a high return on its wartime debt. ${ }^{33}$

However, as figure 2 illustrates, in 1941 the ratio of debt to GNP stood at only 39 percent, whereas in 1946 it was 113 percent. The lower the government debt, the larger the surprise inflation must be to raise the same level of revenue. Depending on how much the costs to surprise inflation increase with the size of the surprise, it may well have been optimal for the government to wait until after the war to inflate.

Nevertheless, this counterfactual implication of the model, or nonoptimal policy on the part of the government, holds for the remainder of the sample. Figure 5 plots the annual percentage change in real government outlays per capita and the unanticipated real returns to government debt. The model implies that these two series should be negatively correlated. In fact, they are positively correlated, with a correlation coefficient of 0.14 .

These unanticipated returns are quite volatile. Although they are roughly zero on average, they frequently exceed 5 percent (in absolute value) of total outlays. Interestingly, these unanticipated returns are roughly the same size as unanticipated tax revenue. Figure 6 plots the difference between actual tax revenue and the CBO's one-year-ahead forecast. Ex post, the $\mathrm{CBO}$ decomposes its forecast error into three components: legislative, economic, and technical or unclassified. Figure 6 also plots these three components of unanticipated tax revenue for the past fifteen years. The total unanticipated revenue series is positively correlated

33. Braun and McGrattan (1993), p. 258. 
Figure 5. Changes in Real Government Expenditure per Capita and Unexpected Real Returns on Government Debt, 1948-99

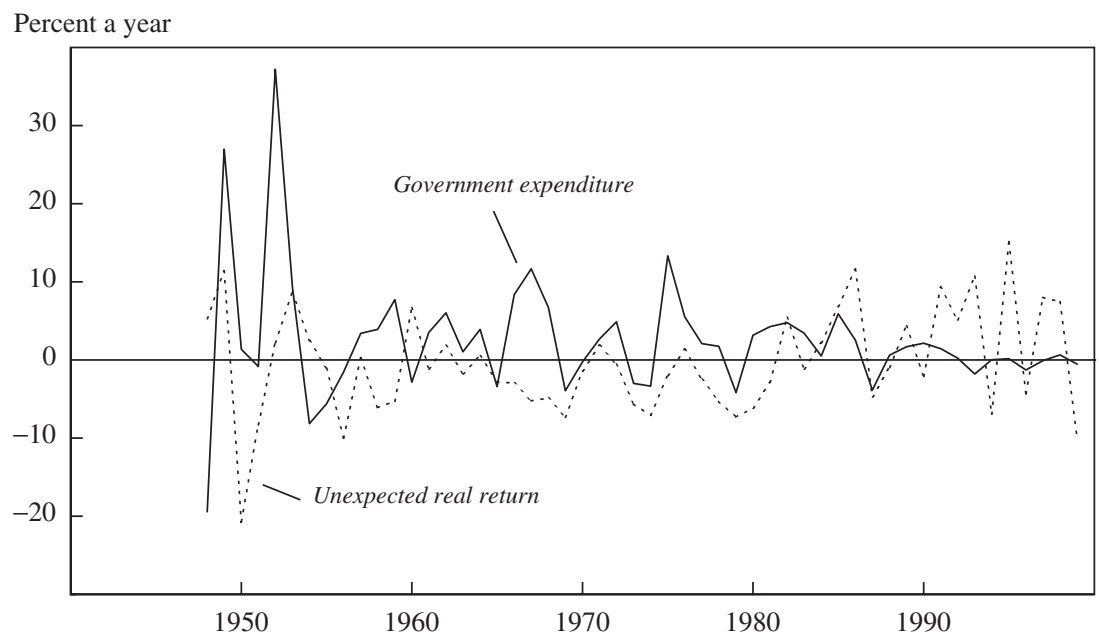

Source: Authors' calculations based on data from CRSP U.S. Government Bond File and U.S. Treasury.

Figure 6. Unexpected Tax Revenue and Its Components, 1985-99a

Percent of expenditure

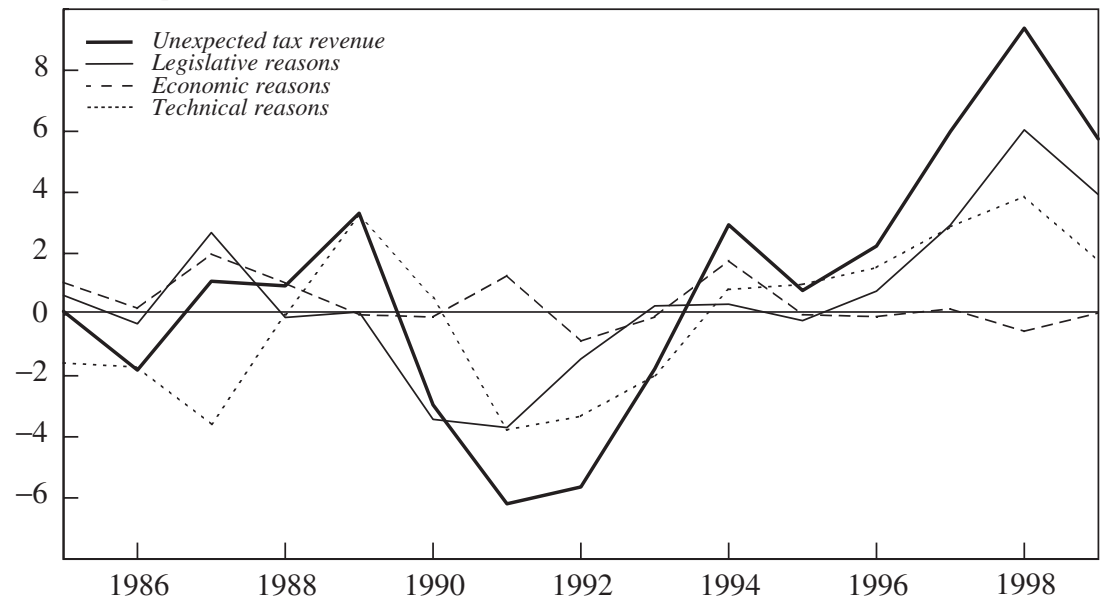

Source: Unpublished CBO data supplied by Mark Booth.

a. Difference between actual revenue and the CBO's one-year-ahead forecast from the previous year. 
(albeit modestly) with our unanticipated return series. The correlation coefficient is 0.05 .

Of course, not all of the unanticipated returns to government debt are generated by shifts in fiscal and monetary policy. Any private sector disturbance that affects real interest rates affects the real market value of the U.S. debt and affects our decomposition of the government's borrowing costs. Also, we have assumed a time-invariant term premium. To the extent that there are systematic, predictable shifts in the term premium over time, our unanticipated returns series will be affected. Nevertheless, we believe that these calculations reasonably approximate the federal government's anticipated and unanticipated borrowing costs.

To decompose the anticipated and unanticipated returns across maturities, figures 7 and 8 plot the expected real return, $\ln \left(E_{t-1} a_{j-1}, t\right)-\ln \left(a_{j, t-1}\right)$, and the unexpected real return for $\ln \left(a_{j-1, t}\right)-\ln \left(E_{t-1} a_{j-1, t}\right)$ for one-year, five-year, and ten-year zero-coupon bonds. There are three things to note. First, the unexpected returns can be quite large, exceeding 20 percent a year in both the positive and the negative direction for the ten-year bond. ${ }^{34}$ The losses, of course, occur during periods of rising inflation or rising interest rates. Second, the longer the maturity of the bond, the greater the volatility of the returns. Third, the real returns on bonds of different maturities move together. These three characteristics of the unexpected returns are important to keep in mind as the stock of outstanding debt is reduced.

Clearly, the return on government debt depends on the maturity structure. Thus the Treasury cites greater control of the maturity structure as one of the advantages of its current buyback program. ${ }^{35}$ Treasury Secretary Lawrence Summers has stated that the Treasury's buyback program will enable the federal government

to prevent what would otherwise be a potentially costly and unjustified increase in the average maturity of our debt, which has grown from 51/4 years in 1997 to

34. We were initially quite surprised by the size of these returns (especially the large anticipated returns for 1982) and thought it might be an artifact of how we computed the zero-coupon bond prices. We therefore substituted Fama-Bliss zero-coupon bond prices for the subsample for which the data sets overlap (which includes 1982). Using FamaBliss prices instead of "Waggoner" prices had no meaningful effect on the results, however. It is important to remember that we are pricing five- and ten-year zero-coupon bonds, not five- and ten-year coupon bonds.

35. U.S. Department of Treasury, Bureau of the Public Debt (1999). 
Figure 7. Expected Real Returns on Zero-Coupon Government Debt, by Maturity, 1947-99

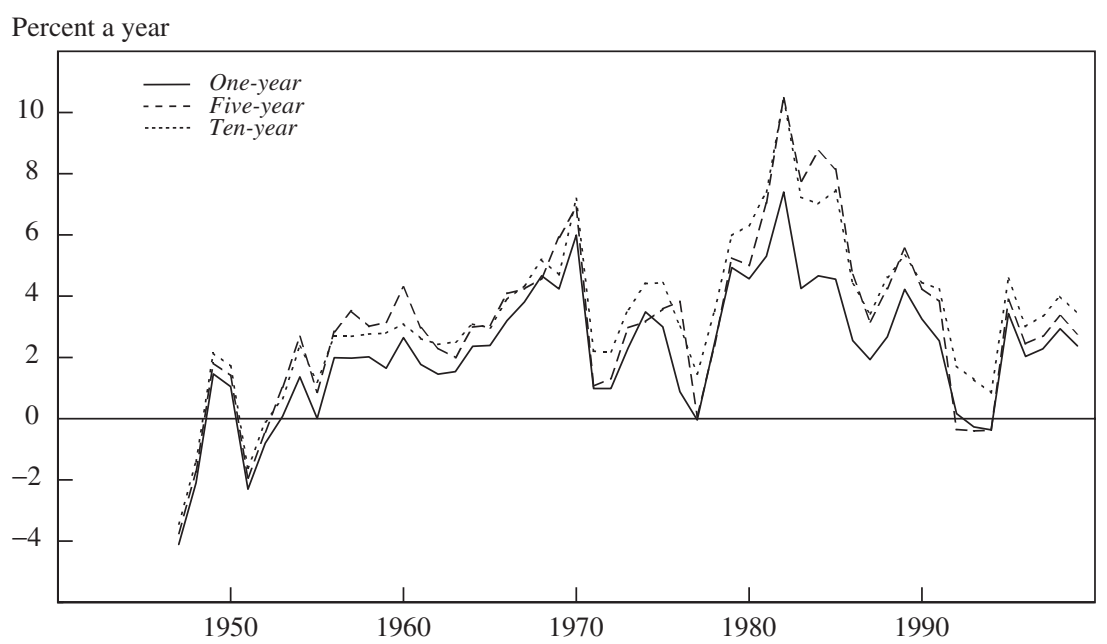

Source: Authors' calculations based on data from CRSP U.S. Government Bond File and U.S. Treasury.

Figure 8. Unexpected Real Returns on Zero-Coupon Government Debt, by Maturity, 1947-99

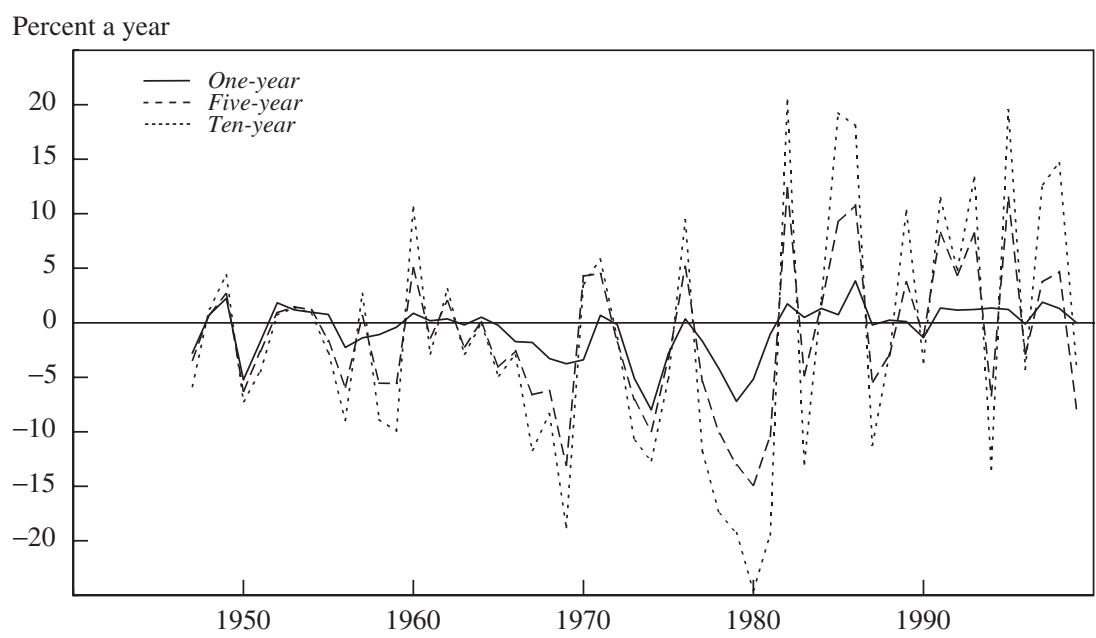

Source: Authors' calculations based on data from CRSP U.S. Government Bond File and U.S. Treasury. 
5\%/4 years in 1999 and, absent countervailing action, would be projected to rise to almost 8 years by 2004 . Over the long run this would impose additional cost on the taxpayers to finance our debt. ${ }^{36}$

However, our analysis suggests that the Treasury might actually want to increase rather than decrease the average maturity of federal debt. Figures 7 and 8 illustrate (and simple arithmetic confirms) that the one-period holding returns on long-term debt are more sensitive to long-term changes to the term structure and the price level than are one-period holding returns on short-term debt. ${ }^{37}$ George Hall and Sargent ran a series of counterfactual exercises assuming that the term structure of interest rates would have been unaffected by changes in the Treasury's debt management policy. ${ }^{38}$ They report that debt management policies weighted toward longer maturities than actually observed would have led to modestly higher, but considerably more variable, interest costs over the period from 1960 to 1995. For a given level of debt, the longer the maturity structure, the smaller the policy response necessary to deliver the same capital gain or loss. Furthermore, in our model, as the initial stock of debt is reduced, the variance of the optimal rate of return to debt increases. That is, holding everything else constant, the smaller the initial level of debt, the greater the swings in interest rates necessary to absorb the same fiscal shock. The combination of a shorter average maturity of debt and a lower level of debt will require larger swings in interest rates to accomplish the same level of shock absorption as before.

Finally, debt is not the only instrument the government has at its disposal to hedge fiscal shocks. Indeed, any outstanding government liability (such as Social Security and Medicare benefits, tax depreciation schedules, veterans benefits, and even the currency) could theoretically be used to absorb fiscal shocks. Milton Friedman, for example, advocated letting the price level alone absorb fiscal shocks. ${ }^{39}$ But although it is easy to imag-

36. U.S. Department of Treasury, Office of Public Affairs (2000).

37. The structural VAR literature (for example, Bernanke, Gertler, and Watson, 1997; Evans and Marshall, 1998) finds that short-term yields are more sensitive than long-term yields to transitory shocks to the federal funds rate. The structural VAR literature measures the response of yields to maturity to purely transitory monetary policy shocks, not the responses of holding-period returns to normal policy actions in response to nonmonetary shocks to the economy.

38. Hall and Sargent (1997).

39. Friedman (1948). 
ine the government having the political will to distribute "capital gains" to the holders of these claims (except for money), it is harder to imagine the government having the political will to distribute "capital losses" to these same holders. Furthermore, the imposition of gains and losses on these other claimants would be difficult to administer, especially if the optimal gains and losses fluctuate rapidly. In contrast, imposing gains and losses on holders of public debt can be implemented automatically, at almost no administrative cost, although there are costs associated with unexpected changes in the price level.

\section{Conclusion}

This paper has sought to address the question, What are the implications for tax smoothing of paying down the federal debt? Under the optimal policy revealed by our general-equilibrium model, a welfare-maximizing government will only choose to pay down the public debt when government spending is expected to increase in the future. Furthermore, public debt provides the government with insurance against fiscal shocks. As the debt is reduced, the returns on that debt must become more variable to provide the same level of insurance. If there are limits on the variability of returns, then by paying down the debt, the federal government impairs its ability to use nominal debt to shift fiscal risk onto its creditors. One consequence is that as the public debt is substantially reduced, other taxes such as distortionary labor and capital taxes become more volatile.

We have documented the state-contingent nature of debt for the second half of the nineteenth century and for the post-World War II period. From 1860 to 1890, in response to large fiscal surpluses, the federal government engaged in a debt buyback program. Through this program and deflationary fiscal policies, the government delivered large ex post returns to bondholders. The timing of these returns is generally consistent with our theory. Since World War II, unanticipated returns on government debt have been high and volatile, but the timing of these returns has not always corresponded to the timing implied by the model. Although government securities are nominally risk free, their real returns are not. The state-contingent nature of these real returns provides the government insurance against shocks, and this insurance will not be easily replaced as the stock of debt declines. 


\section{Comments and Discussion}

Benjamin M. Friedman: The dramatic turnaround in the U.S. government's budget position, from a unified deficit of $\$ 290$ billion (equal to 4.7 percent of GDP) in the 1992 fiscal year to a projected unified surplus of $\$ 232$ billion (2.4 percent of GDP) in fiscal 2000, is one of the most remarkable developments in American fiscal history. The prospect that the surplus might not simply persist but grow, if current tax and spending policies continue, is even more remarkable. Were this to happen, the U.S. Treasury's outstanding publicly traded debt would continue to shrink, as it is shrinking now. Within a decade or so, it would disappear altogether.

Nobody expects this hypothetical situation to become reality. Neither tax nor spending policies will remain unchanged. Even so, for at least a few years the government's debt probably will either decrease absolutely or, at a minimum, grow far more slowly than the U.S. economy. Hence thinking through the implications of a shrinking (even if not totally vanishing) government debt is a useful and potentially important object of economic analysis. The goal of these two interesting papers is to do just that.

The central point of the carefully executed paper by George Hall and Stefan Krieger is that governments may sometimes find it useful to inflate away their outstanding debt, and that it is difficult to do so if there is no debt outstanding to begin with. It is hard to disagree with this basic logic. The implications to which it may give rise are another matter, however. Although the theoretical model that the authors present is sound enough, as such models go, I am skeptical about applying it to draw policy conclusions about the paydown of U.S. government debt now in progress. Doing so places at center stage what should be at most a second-order mat- 
ter, while omitting altogether the considerations that matter most in the present context. Using the model to evaluate the conduct of fiscal policy during earlier periods of U.S. history, as the authors do for the post-Civil War experience and for the second half of the twentieth century, leads to conclusions that seem at first glance puzzling. The reason is again the focus on matters that should be of second-order importance compared with what is left out.

To begin, it is useful to be straightforward about what the paper is about, namely, inflation and deflation. The authors acknowledge that "changes in inflation" are necessary to implement what their model says is the optimal policy, and they recognize that these changes may impose substantial costs "in the real world" (albeit not in their model). Because their analysis is based on their model, however, for the most part these costs-indeed, even the words "inflation" and "deflation"- - are absent from the discussion. The authors instead use the more neutral term "statecontingent returns" to indicate that what an investor receives in exchange for holding the government's debt depends on the state of the economy at the time, which cannot be fully known in advance.

It is true that the return to holding government debt can vary for reasons other than changes in inflation. Real interest rates do vary over time. Sometimes the Treasury pays a premium to buy back its bonds (on this the historical details that the authors present from the 1880s are fascinating). But as a practical matter, in an economy in which almost all government debt is nominally noncontingent, an especially low return on that debt over any given period mostly means that there has been surprise inflation, whereas an especially high return mostly means surprise deflation. Moreover, the inflation or deflation rates that the authors' model indicates as optimal are very large. The optimal annual returns on government debt implied by simulating the model under the authors' chosen parameters for the "large shock" example (which corresponds to having to fight a major war) range from -61 percent to +135 percent. Even in the "small shock" example the optimal annual returns range from -10 percent to +18 percent. It is hard to know what interpretation other than unexpected inflation and deflation to place on these values.

In contrast to the central role that inflation and deflation play in the authors' model, many of the important questions at issue in today's discussion of the government surplus and the resulting debt paydown appear nowhere in this analysis. The model includes no capital, hence no invest- 
ment. The much-discussed idea that the shift from government dissaving to government saving might foster productive capital formation is therefore missing. The economy in the model is always at full employment. Hence there is no issue of any challenge to monetary policy in steering the economy during a swing from fiscal stimulus to fiscal restraint. Because the whole point of the model is that returns to holding government debt are uncertain, any discussion of how the current debt paydown represents a taking away of what market participants regard as a risk-free asset is missing. Indeed, it would be out of place were it included (more on this below).

Instead the model focuses on the role of unexpectedly low or high returns on government debt as a way of providing the government with a form of insurance against unforeseen shocks to its spending. But if this is the central focus of the paper, the authors need to do more than simply note in passing that "in the real world" an inflation that produces returns of -61 percent a year, or a deflation that delivers a return of 135 percent a year, may be costly. Indeed, consideration of this paper's model in the context of the broader literature on which it draws suggests an order of priorities that may strike many readers as odd, if not backward. That broader literature invariably tells us that inflation is bad-sufficiently bad that it is wrong to resort to rising prices and wages to boost output and employment, and sufficiently bad that, if inflation does somehow increase, it is worth bearing substantial real costs to get rid of it. But as bad as inflation may be, tax distortions, in the authors' view, are apparently worse. What determines optimal policy in their model is the desire to smooth tax rates over time, and therefore to hold to a minimum the resulting distortions to people's willingness to work. Allowing inflation, even big inflation, in order to minimize these tax distortions is not just acceptable but optimal.

An example will help illustrate the point. The largest welfare gain that the authors' model imputes to the use of "state-contingent debt" in the presence of distortionary taxation - this appears, not surprisingly, in the "large shock" experiment-amounts to a difference of 3.1 percent in the implied permanent level of consumption. (This result is obtained by subtracting the 7.9 percent reported in table 2 , experiment 6 , from the 11.0 percent reported in experiment 7.) No one would suggest that a 3.1 percent difference in steadystate consumption is small. But when one compares this gain with the likely costs of an inflation that reaches 135 percent per annum (or -61 percent), placing that gain at center stage becomes a puzzling choice of focus. 
These same contrasts between the assumptions on which the model rests and the world of actual fiscal policy carry over to the paper's discussion of U.S. fiscal history. The authors conclude that the high returns earned by holders of U.S. government debt in the decades after the Civil War reflect a policy that closely resembles the optimal policy implied by their model. But the two decades following 1873 constituted what was known at the time as the "Great Depression," an economic experience centered around prolonged and deep deflation. The economy-wide average price level declined by 20 percent during the 1870 s and by a further 16 percent by the mid-1890s. ${ }^{1}$ Real economic distress was widespread and worsened as time went on. (By 1894, just before the deflation ended, unemployment was 18 percent.) Not surprisingly, this protracted deflation and its connections to U.S. adherence to the gold standard became the single most divisive political issue of the time.

But given their emphasis on tax distortions, what is especially surprising about the authors' application of their model to this period is that, as they straightforwardly recognize, the United States had no income tax then. Whereas the model assumes that the government's source of revenue is a labor income tax, which distorts people's willingness to work, most federal revenue in the late nineteenth century came from tariffs, which instead distort people's willingness to consume foreign-made products. To the extent that the tariff was there for a reason-to foster the development of the nation's newly burgeoning manufacturing industriesthe resulting "distortion" was not a harmful by-product of the need to raise revenue but an outcome desired on its own merits.

In the post-World War II period, of course, the United States did have an income tax. The authors' argument that postwar U.S. fiscal policy was suboptimal does not rest on directly observing the movement of tax rates, however, or on any estimate of the distortionary effects of these taxes, but rather on the timing with which the government inflated away the debt. (During the pre-Reagan era, 1946-80, the combination of inflation and economic growth reduced the government's debt-GDP ratio from 1.09 to 0.26.) The government's main failure, according to the model, seems to have been that it waited until after the war to inflate away the debt, rather than going ahead with a major inflation during the war years. But it is not 
hard to imagine motivations, not incorporated in the model, for restraining inflation while the country was at war.

The paper by Michael Fleming adopts an entirely different tone, style, and direction. More important, the fundamental motivating presumption of Fleming's analysis is directly opposite to that of Hall and Krieger. The central point of Hall and Krieger's paper is, again, that the return to holding government debt is, and ought to be, variable (more specifically, that it should be state-contingent, either explicitly or by exploiting the debt's nominal denomination). Moreover, the authors' model suggests a very wide range for this state-contingent variation. By contrast, the central point of Fleming's paper is that the returns to holding government debt are, for many practical purposes, risk-free. As he states at the beginning, "yields of U.S. Treasury securities are ... a proxy for risk-free interest rates." And a little later, "Because Treasuries are considered free of default risk, their yields represent risk-free rates of return. These risk-free rates are used in a variety of analytical applications.... In estimating the capital asset pricing model, for example, the rate on a Treasury bill is typically used as a proxy for the risk-free rate."

An investigation of the implications of state-contingent returns on government debt is a worthwhile economic exercise. So is an analysis resting on the presumed risk-free properties of government debt. But it is unlikely that both will shed useful practical light on the same real-world situation. In this case I vote for Fleming's approach. The reason there is now so much discussion of the implications of a potential disappearance of U.S. government debt is precisely that, as in his analysis, market participants perceive this debt to be risk-free in important dimensions; indeed, it is the only such risk-free asset.

Fleming's paper is thoughtful, carefully researched, and highly useful in addressing many of the practical issues that have arisen from the current debt paydown in the United States. For example, the evidence he provides that liquidity in parts of the Treasury securities market has already deteriorated is very interesting. The material on benchmarks and hedging is particularly insightful. Especially so is the suggestion that federal agency securities might even be superior to Treasuries for many hedging purposes, because their yields apparently incorporate an element of private credit risk that renders them more highly correlated with yields on the assets that market participants typically seek to hedge. Fleming's discussion also nicely lays to rest concerns that the shrinking supply of 
Treasury securities will pose operational problems for the Federal Reserve's conduct of monetary policy.

In sum, there is something for everyone in these two contributions. Theory buffs will want to read Hall and Krieger's paper. Readers interested in the practical consequences of the extraordinary movement now under way in U.S. fiscal policy can turn to Fleming's.

Mark Gertler: Let me begin by wishing Michael Fleming, George Hall, and Stefan Krieger better luck than Gary Burtless had nearly twenty years ago. If memory serves me correctly, Burtless wrote a paper around 1980 on the same issue of the implications of eliminating government debt. At that time, the ratio of government debt to GDP had been declining steadily for nearly forty years, as figure 2 of the paper by Hall and Krieger confirms. Then, as now, official budget projections predicted a string of future surpluses, making the move to zero government debt a real possibility. But of course, along came the tax cuts of the 1980s, and the stock of government debt skyrocketed. History suggests, therefore, that official budget forecasts are associated with a high degree of variance. Yet contingency planning is in order, and in this regard, the present authors have produced an interesting set of papers.

Read together, these papers emphasize three considerations of moving to zero government debt:

- the loss of a fiscal shock absorber that would help smooth shifts in distortionary taxes,

- the potential loss of liquidity in financial markets, and

- the implications for open market operations by the Federal Reserve.

The authors seem to suggest that the first consideration is quite important, that the second is probably also important. In contrast, they indicate that the third consideration is probably not important at all, even though eliminating the debt would mean that the Federal Reserve, for the first time in modern history, would have to engage in trading securities that have some credit risk.

I confess that my priors before reading these papers were nearly the reverse. My view was that the loss of liquidity in financial markets from eliminating government debt was potentially of paramount concern. Similarly, I imagined that the prospect of the Federal Reserve directly trading private securities in open market operations, thereby injecting itself directly into the credit allocation process, could have profound implica- 
tions, particularly for central bank independence and moral hazardinduced risk taking in financial markets. At the same time, I had not given any thought to the implications of zero government debt for tax smoothing. I cannot say to what extent the authors have succeeded in shifting my priors. Instead I will simply raise some issues that might help clarify all three of their considerations.

The argument that the elimination of government debt removes an important fiscal shock absorber runs as follows. In a conventional neoclassical framework the deadweight loss from taxation is approximately convex in the marginal tax rate. Given such a framework, it is desirable to keep marginal tax rates from fluctuating unnecessarily, and hence it is desirable to issue state-contingent (that is, equity-like) government debt. By letting the holders of government bonds absorb, through unexpected capital losses and gains, the risk of variation in net fiscal needs, the government is able to reduce the variation in marginal tax rates. Hall and Krieger use a simple calibrated general-equilibrium model to illustrate this argument. They also examine the historical evidence to see how well the predictions of the model match the data.

I find the calibration exercise interesting, but it does not seem to answer unambiguously whether a policy of using debt as a fiscal shock absorber yields significant quantitative benefits. If the variability of government expenditure matches that observed around the time of World War II, the answer seems to be yes. On the other hand, to the extent this variability resembles the record since 1950, the benefits seem negligible. Put differently, in the absence of a significant likelihood of a major war, the tax smoothing benefits from state-contingent debt do not seem large. I suppose that other shocks (such as a shift in trend productivity) could also, in principle, affect government revenue in a way that enhances these benefits, but it would be useful to demonstrate this explicitly.

A second issue is one of pragmatism. In reality, governments do not issue fully state-contingent debt; rather, their debt is typically fixed in nominal terms. Accordingly, implementing the fiscal risk sharing policy that Hall and Krieger have in mind boils down in practice to generating unanticipated inflation, when a capital loss for bondholders is required, and unanticipated deflation, when a capital gain is required. Let us leave aside the fact that a central bank's control over inflation is extremely imprecise in practice. Even so, the medicine may be worse than the cure. Since there are clear resource costs associated with inflation (relative price 
distortions, among others), implementing the required state-contingent transfers is not likely to be costless.

In a related vein, I think we have learned over the last twenty or thirty years that it is probably best to remove central banks from fiscal operations and have them focus squarely on inflation and macroeconomic stabilization. Hall and Krieger assume that there will be no loss of credibility if a central bank generates an unanticipated inflation to shore up the government's fiscal situation. This assumption may be correct if the public perceives the unanticipated inflation as the outcome of a preagreed statecontingent transfer policy to which the central bank will stick-that is, if the public perceives the government can credibly commit to such a policy. But the private sector may instead believe that the central bank might not make good on its promise to provide capital gains in good times, through deflation. This then leads to the problems of inflationary bias emphasized originally by Finn Kydland and Edward Prescott and by Robert Barro and David Gordon. ${ }^{1}$

A final question is whether the U.S. government has in practice been following this kind of state-contingent transfer policy since World War II. Hall and Krieger's measurement of the returns on government debt during this period, particularly the breakdown into anticipated and unanticipated components, is quite interesting. It is not clear to me, however, that the pattern of unanticipated capital gains and losses is consistent with their fiscal insurance theory. According to this theory, unanticipated capital losses on government debt result from the central bank generating an unanticipated inflation to make up a revenue shortfall. In fact, Hall and Krieger's figure 4 suggests that the significant unanticipated capital losses on government debt that actually occurred are associated with periods of tight monetary policy - periods when the central bank was trying to reduce inflation, not raise it. These periods include not only the familiar tight money episodes of recent history but also 1994, when the bond market collapsed in anticipation of monetary tightening. Accordingly, one interpretation of the pattern of capital losses is that, in response to existing high inflation, the Federal Reserve raises interest rates to slow the economy, and this in turn generates a capital loss to bondholders, particularly long-term bondholders. Hall and Krieger might do well to think 
about how to reconcile this scenario with the fiscal transfer theory they emphasize.

With respect to the impact of declining government debt on financial market liquidity, the key issues are the implications for the efficiency of those markets and the extent to which the economy is exposed to the possibility of a financial crisis. On these questions Michael Fleming presents an array of interesting evidence to suggest that investors do value the liquidity services afforded by government debt. Not only are they willing to pay a premium to hold such debt, as Fleming shows, but indeed this premium appears to have risen as the supply of government debt has dwindled. This finding of supply effects on price at different maturities is particularly compelling evidence of a role for government debt in liquidity provision.

Why do government bonds provide liquidity services? Their homogeneity and absence of credit risk make them easy to sell on short notice and widely accepted as collateral. Thick markets have therefore emerged to facilitate trading in these instruments. The question is whether, if government debt disappears, an alternative instrument will emerge that can provide liquidity services on a similar scale. The candidates often mentioned are agency securities and interest rate swaps. Agency securities are private instruments with an implicit government guarantee (in the form of a backup line of credit with the Treasury). Swaps are purely private instruments. Both types of instrument, although well toward the safe end of the spectrum of financial instruments, have some degree of credit risk. Thus, neither is currently a perfect substitute for government debt, as Fleming's evidence on quality spreads suggests.

To reinforce this point, figure 1 below plots the spreads between tenyear agency securities and comparable Treasury bonds and between tenyear interest rate swaps and Treasuries, from 1998:1 to 2000:2. The figure shows that both spreads widened in the wake of Russian bond default in the third quarter of 1998, indicating clearly that investors were willing to pay an additional premium for U.S. government debt during these turbulent times. Both spreads continued to widen following the tightening of monetary policy that began in 1999. Another contributing factor over this time was the dwindling supply of long-term government debt.

The behavior of these quality spreads is not unique to these times. In general during periods of aggregate economic distress, these spreads tend to widen, reflecting at least in part an increased demand for liquidity. 
Figure 1. Yield Spreads between Ten-Year Swaps, Agency Bonds, and Corporate Bonds and Ten-Year Treasury Bonds, 1998-2000 ${ }^{\mathrm{a}}$

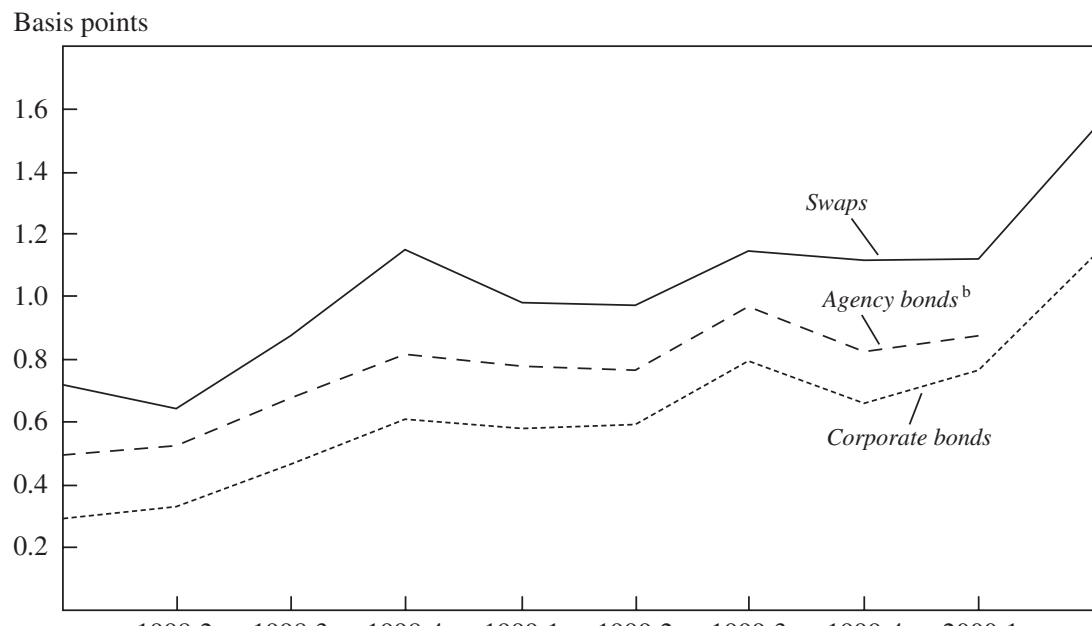

$\begin{array}{llllllll}1998: 2 & 1998: 3 & 1998: 4 & 1999: 1 & 1999: 2 & 1999: 3 & 1999: 4 & 2000: 1\end{array}$

Source: Federal Reserve Bank of New York.

b. Fannie Mae benchmark securities.

Figure 2 plots the spread between swaps and Treasuries over the whole of the past decade (data on the spread between agency debt and Treasuries are not available) and shows a widening of the spread during the 1991 recession, as well as in the recent period.

These data suggest not only that there is a demand for a liquid instrument, but also that this demand increases in bad times. If government debt disappears, will an alternative vehicle emerge to meet this demand? Let me be more concrete about the implications of this question. Domestic financial institutions hold government bonds as a buffer stock against changing credit conditions. For example, we know that when monetary policy tightens or some other disturbance to credit markets occurs, commercial banks often shed these buffer stocks so that they may continue to lend. Indeed, in a recent paper, Marc Saidenberg and Philip Strahan argue that a key factor mitigating the impact of the Russian crisis was U.S. commercial banks' reserve holdings of liquid government debt. ${ }^{2}$ As the bond 
Figure 2. Yield Spreads between Ten-Year Swaps and Ten-Year Treasury Bonds, 1988-2000

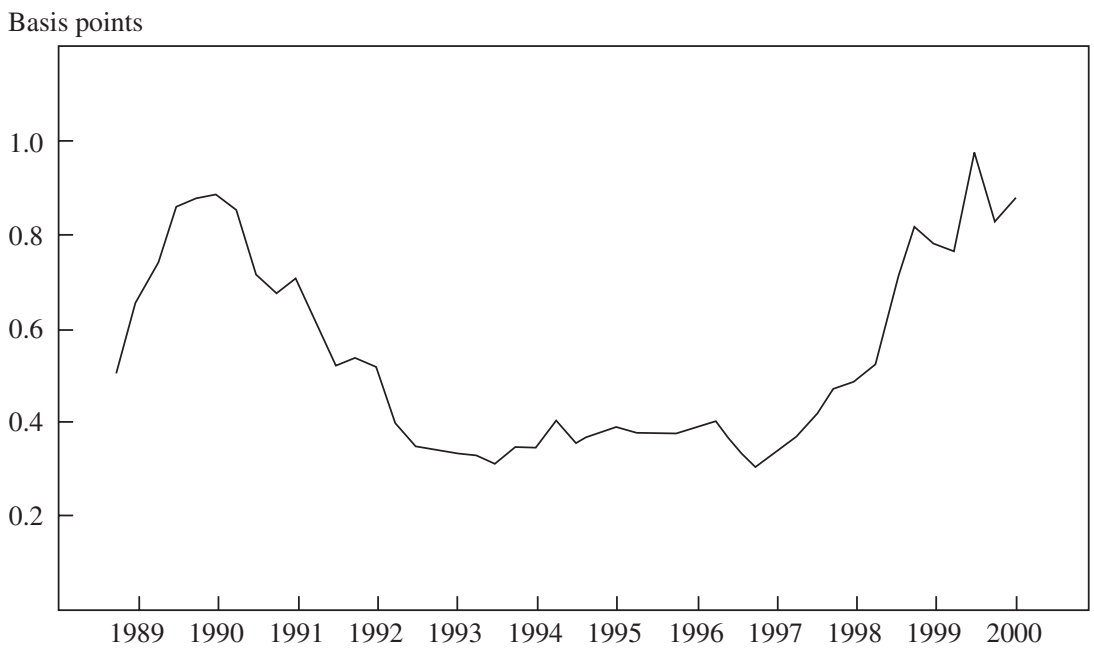

Source: Federal Reserve Bank of New York.

a. Through second quarter.

market temporarily dried up during the crisis, borrowers turned to these commercial banks. Because the banks were sufficiently liquid, they were able to meet credit needs with minimal disruption. In this instance, therefore, the availability of liquid government debt was central in helping avoid a meltdown in financial markets. Whether agency debt or other private instruments could assume this role in the event of a similar crisis is the key question.

Finally, does it matter whether the Federal Reserve conducts open market operations using securities with some degree of private credit risk? Currently the Fed injects high-powered money into the economy by two methods: open market operations and lending through the discount window. In current practice there are important distinctions between the two. The former is the chief means by which the Federal Reserve exerts control over the federal funds rate. The latter serves to meet the transitory liquidity needs of commercial banks and (indirectly) other money market participants, with the aim of avoiding financial crises.

The cost of discount window lending, as we know, is the potential for moral hazard: the availability of short-term credit from the central bank 
may encourage excessive risk taking. For this reason, I believe, under the current system there is an implicit firewall between open market operations and discount window lending. Monetary policy (open market operations) is kept distinct from the process of credit allocation and, to the extent possible, free from the direct pressure to bail out troubled financial institutions.

The elimination of government debt could lead to a breakdown in this firewall. The Fed's entire balance sheet would consist of securities with some degree of private credit risk. There could then be pressure on the central bank to maintain the prices of particular classes of securities. Agency debt is a case in point. No less an authority than Alan Greenspan has warned that implicit subsidies have encouraged Fannie Mae and Freddie Mac to assume greater risk in their portfolios than is desirable. Making these securities the chief instrument for open market operations can only enhance this problem. Perhaps my concerns here are overblown, but I have yet to see them concretely addressed.

General discussion: Commenting on the paper by Michael Fleming, Olivier Blanchard observed that, if it wanted to maintain a Treasury bill market, the government could do so even if net debt was vanishing, by issuing bills to buy private debt, either directly or through a new agency. Vincent Reinhart pointed out that the Fed already owns a small amount of agency debt in its open market portfolio and has decided to form a working group to study the general issue that Blanchard raised. He noted that it is unclear whether the Fed balance sheet of the future would include agency securities or some other financial assets. Douglas Elmendorf added that, as the Fed expands its holdings of other assets, a unified government balance sheet that combines the Fed with the rest of the government will change. That balance sheet now has essentially no financial assets and a lot of liabilities, but it will soon contain noticeable amounts of financial assets from outside the government in order to keep government liabilities in the hands of the public. Eventually, as Fed purchases become insufficient, financial assets would have to be acquired elsewhere in the government in order to keep enough gross government debt outstanding while preserving the benefits of additional capital formation that larger unified surpluses provide. James Duesenberry stressed the importance of keeping political influence out of the evolution to such a different regime. Mark Gertler noted that Alfred Broaddus and Marvin Good- 
friend of the Federal Reserve Bank of Richmond have proposed forming a Treasury intermediary to buy private securities as Elmendorf had outlined. Their motivation was the desire to keep open market operations in Treasury bills and out of the private credit allocation process. Doing so separates allocation, with its political pressures, from the conduct of monetary policy, but leaves the Treasury with the responsibility to resist those pressures.

Robert Hall argued that, if the government saw a duty to provide a highly liquid instrument that the public demanded, the focus should be on combining high-powered money with Treasury bills. Rather than allowing imperfect substitutes, such as agency debt, to develop, he suggested that a single form of money that also paid interest, which the Fed would provide as it now provides high-powered money, would better serve the purpose. The Fed would then conduct monetary policy by varying the rate of interest paid on the hybrid instrument. Matthew Shapiro interpreted the spikes in government debt prices at recent auctions as brief dislocations associated with the transition to a different debt regime with less Federal debt and a sparser term structure. He also found it useful to distinguish the role of government debt as a yardstick from its role in providing markets with an array of safe securities of varying maturities. He noted that Hall's interest-bearing money not only would provide a yardstick but could also fill this other current role of government debt if it were issued in a range of differing maturities.

Turning to the paper by George Hall and Stefan Krieger, several panelists shared the view of Benjamin Friedman and Mark Gertler that issuing nominal debt and pursuing a state-dependent price policy was not a feasible way to achieve optimal state-contingent debt. In the real world, in contrast to the authors' model, inflation has real costs. They suggested that variations in the price level of the magnitude suggested by the authors' simulations would be extremely costly. Robert Hall observed that the logic behind indexing debt, a logic with which he agreed, is that it is desirable to reduce the risks to bondholders from unexpected inflation. In the authors' model, in contrast, issuing such debt is a bad idea, because it would eliminate the means for insuring against unexpected changes in government expenditure. Hall suggested that, if the government is to issue contingent claims, the contingencies should be made explicit rather than through the back door of price-level adjustments. Gregory Mankiw agreed with Hall, observing that economists from all points on the political spec- 
trum have been strong advocates of indexation. Following the logic of the paper and introducing costs to inflation would actually suggest the issuance of negatively indexed debt, so that there would be larger statecontingent changes in the value of debt for any given movement of the price level.

Christopher Sims found the arguments for indexation too facile and noted that it is no accident that debt in all advanced economies is almost entirely nominal. He suggested that the reasons why the government issues nominal debt are similar to the reasons why a substantial fraction of firms' capital is financed by equity. By having a considerable part of its liabilities in a form with contingent returns (nominal debt for the government, equity for a firm), a firm or a government can make bankruptcy, or inefficient changes in expense and revenue flows to avoid bankruptcy, an unlikely event, despite unpredictable disturbances to revenues and expenses. Sims went on to suggest that issuing debt explicitly contingent on government expenditure raises a host of moral hazard problems, and he noted that such debt does not exist anywhere in the world. Indeed, he thought that one of the advantages of nominal debt is that it is not possible to generate a contingent return on it without at the same time generating a shock to all kinds of contracts in the rest of the economy. The cost of those shocks provides an effective restraint on overuse of the mechanism.

In the authors' model, variations in the returns on government debt are a way to avoid costly fluctuations in the tax rate. Jeffrey Liebman and Janet Yellen both noted that, in a country with an aging population, tax smoothing is a justification for paying off the debt in anticipation of future increases in government spending on retirement programs. Since the model does not include capital, it is missing the mechanism by which current debt reduction can smooth taxes by providing for future consumption or government expenditure.

Olivier Blanchard and Jonathan Parker drew attention to the distinction between gross and net government debt. In principle, there is no reason why the government cannot purchase claims on real assets and issue nominal debt. Parker noted that this is effectively what would happen if some of the proposals for diversification of the social security trust fund were implemented. Government funding of individual retirement saving accounts or tax subsidies for private saving would have similar effects. 


\section{References}

Amihud, Yakov, and Haim Mendelson. 1991. "Liquidity, Maturity, and the Yields on U.S. Treasury Securities.” Journal of Finance 46(9): 1411-25.

Auerbach, Alan, and William G. Gale. 2000. "Perspectives on the Budget Surplus.” Working Paper 7837. Cambridge, Mass.: National Bureau of Economic Research (August).

Balke, Nathan S., and Robert J. Gordon. 1989. "The Estimation of Prewar Gross National Product: Methodology and New Evidence." Journal of Political Economy 97(1): 38-92.

Bank for International Settlements. 1999. "A Review of Financial Market Events in Autumn 1998." Basle. (Available at www.bis.org/publ/index.htm.)

Barro, Robert. 1979. "On the Determination of the Public Debt." Journal of Political Economy 87(5): 940-71.

Barro, Robert J., and David B. Gordon. 1983. "A Positive Theory of Monetary Policy in a Natural Rate Model.” Journal of Political Economy 91(4): 589-610.

Bennett, Paul, Kenneth Garbade, and John Kambhu. 2000. "Enhancing the Liquidity of U.S. Treasury Securities in an Era of Surpluses.” Federal Reserve Bank of New York Economic Policy Review 6(1): 89-119.

Bernanke, Ben S., Mark Gertler, and Mark Watson. 1997. "Systematic Monetary Policy and the Effects of Oil Price Shocks." BPEA, 1:1997, 91-142.

Braun, R. Anton, and Ellen R. McGrattan. 1993. "The Macroeconomics of War and Peace." In NBER Macroeconomics Annual 1993, edited by Olivier Blanchard and Stanley Fisher. MIT Press.

Chari, V. V., Lawrence J. Christiano, and Patrick J. Kehoe. 1991. “Optimal Fiscal and Monetary Policy: Some Recent Results." Journal of Money, Credit, and Banking 23(3, part 2): 519-39.

1994. "Optimal Fiscal Policy in a Business Cycle Model." Journal of Political Economy 102(4): 617-52.

Chari, V. V., and Patrick J. Kehoe. 1999. "Optimal Fiscal and Monetary Policy." In Handbook of Macroeconomics, vol. 1, edited by John B. Taylor and Michael Woodford. Amsterdam: Elsevier Science.

Christiano, Lawrence J., and Terry J. Fitzgerald. 2000. "Understanding the Fiscal Theory of the Price Level." Unpublished paper. Northwestern University (April).

Congressional Budget Office. 2000. "The Budget and Economic Outlook: An Update." Washington (July).

Duffie, Darrell. 1996. “Special Repo Rates.” Journal of Finance 51(2): 493-526.

Dupont, Dominique, and Brian Sack. 1999. "The Treasury Securities Market: Overview and Recent Developments." Federal Reserve Bulletin 85(12): 785-806. 
Estrella, Arturo, and Frederic S. Mishkin. 1998. "Predicting U.S. Recessions: Financial Variables as Leading Indicators." Review of Economics and Statistics 80(1): 45-61.

Evans, Charles L., and David A. Marshall. 1998. "Monetary Policy and the Term Structure of Nominal Interest Rates: Evidence and Theory." CarnegieRochester Conference Series on Public Policy 49(1): 53-111.

Fabozzi, Frank J., and Michael J. Fleming. 2000. "U.S. Treasury and Agency Securities." In Handbook of Fixed Income Securities, 6th ed., edited by Frank J. Fabozzi. McGraw-Hill.

Fleming, Michael J. 1997. "The Round-the-Clock Market for U.S. Treasury Securities." Federal Reserve Bank of New York Economic Policy Review 3(2): 9-32.

2000a. "The Benchmark U.S. Treasury Market: Recent Performance and Possible Alternatives." Federal Reserve Bank of New York Economic Policy Review 6(1): 129-45.

2000b. "Treasury Market Liquidity." Unpublished paper. Federal Reserve Bank of New York (June).

Friedman, Milton. 1948. "A Monetary and Fiscal Framework for Economic Stability." American Economic Review 38(3): 245-64.

Hall, George J., and Thomas J. Sargent. 1997. "Accounting for the Federal Government's Cost of Funds." Federal Reserve Bank of Chicago Economic Perspectives 21(4): 18-28.

Joines, Douglas H. 1981. "Estimates of Effective Marginal Tax Rates on Factor Incomes." Journal of Business 54(2): 191-226.

Jordan, Bradford D., and Susan D. Jordan. 1997. "Special Repo Rates: An Empirical Analysis." Journal of Finance 52(5): 2051-72.

Kamara, Avraham. 1994. "Liquidity, Taxes, and Short-Term Treasury Yields." Journal of Financial and Quantitative Analysis 29(3): 403-17.

Keane, Frank. 1996. "Repo Rate Patterns for New Treasury Notes.” Federal Reserve Bank of New York Current Issues in Economics and Finance 2(10).

Kydland, Finn E., and Edward C. Prescott. 1977. "Rules Rather Than Discretion: The Inconsistency of Optimal Plans." Journal of Political Economy 85(3): 473-91.

Lucas, Robert E., Jr., and Nancy L. Stokey. 1983. “Optimal Fiscal and Monetary Policy in an Economy without Capital." Journal of Monetary Economics 12(1): 55-93.

Marcet, Albert, Thomas J. Sargent, and Juha Seppälä. 2000. "Optimal Taxation without State-Contingent Debt.” Unpublished paper. Stanford University (June).

McCulloch, J. Huston. 2000. "The 'Bellwether' 30-Year Treasury Bond Is an Exceptionally Bad Investment." Ohio State University. (Available at economics.sbs.ohio-state.edu/jhm/ts/otr.htm, February 18.) 
McGrattan, Ellen R. 1994. "The Macroeconomic Effects of Distortionary Taxation." Journal of Monetary Economics 33(3): 573-601.

Office of Management and Budget. 2000. Budget of the United States Government, Fiscal Year 2001. (Mid-Session Review). Washington: Government Printing Office.

Ohanian, Lee E. 1997. "The Macroeconomic Effects of War Finance in the United States: World War II and the Korean War." American Economic Review 87(1): 23-40.

Saidenberg, Marc R., and Philip Strahan. 1999. "Are Banks Still Important for Financing Large Businesses?" Current Issues in Economics and Finance 5(12). New York: Federal Reserve Bank of New York.

Sargent, Thomas J. 1993. "Fact or Fiction: Shortening Debt Maturity Lowers Interest Costs." Chicago: Catalyst Institute.

- 2000. "Comment on 'Fiscal Consequences for Mexico of Adopting the Dollar' by Christopher A. Sims.” Unpublished paper. Stanford University (June).

Sims, Christopher A. 2000. "Fiscal Consequences for Mexico of Adopting the Dollar." Unpublished paper. Princeton University (June).

Taus, Esther Rogoff. 1943. Central Banking Functions of the United States Treasury, 1789-1941. Columbia University Press.

U.S. Department of the Treasury, Bureau of the Public Debt. 1999. "Marketable Treasury Securities Redemption Operations." Federal Register 64(150): 42626-29.

U.S. Department of the Treasury, Office of Public Affairs. 2000. "Statement of Treasury Secretary Lawrence Summers." Washington (January 13).

U.S. General Accounting Office. 1998. "Social Security Financing: Implications of Government Stock Investing for the Trust Fund, the Federal Budget, and the Economy." Report AIMD/HEHS-98-74 (April). Washington.

—. 1999. "Federal Debt: Debt Management in a Period of Surplus." Report AIMD-99-270 (September). Washington.

Waggoner, Daniel F. 1997. "Spline Methods for Extracting Interest Rate Curves from Coupon Bond Prices.” Working Paper 97-10. Atlanta: Federal Reserve Bank of Atlanta.

Woodford, Michael. 1998. "Public Debt and the Price Level." Unpublished paper. Princeton University (June). 
